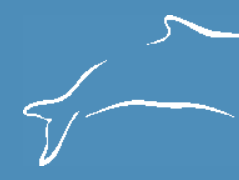

\begin{tabular}{|c|c|}
\hline \multicolumn{2}{|c|}{ Article Info } \\
\hline Manuscript type & Review \\
\hline \multicolumn{2}{|l|}{ Article history } \\
\hline Received & 30 May 2012 \\
\hline Received in revised form & 17 June 2013 \\
\hline Accepted & 24 June 2013 \\
\hline Available online & 26 December 2015 \\
\hline \multicolumn{2}{|c|}{$\begin{array}{l}\text { Keywords: Lutrinae, Mustelidae, anthropogenic pressures, } \\
\text { apex predator, ecotourism, endangered species }\end{array}$} \\
\hline \multicolumn{2}{|c|}{ Responsible Editor: Danielle Lima } \\
\hline \multicolumn{2}{|c|}{$\begin{array}{l}\text { Citation: Duplaix, N., Evangelista, E. and Rosas, F.C.W. (2015) } \\
\text { Advances in the study of giant otter (Pteronura brasiliensis) } \\
\text { ecology, behavior, and conservation: a review. Latin American } \\
\text { Journal of Aquatic Mammals 10(2): } 75-98 \text {. } \\
\text { http://dx.doi.org/10.5597/lajam00200 }\end{array}$} \\
\hline
\end{tabular}

\title{
Advances in the study of giant otter (Pteronura brasiliensis) ecology, behavior, and conservation: a review
}

\author{
Nicole Duplaix ${ }^{\dagger, *}$, EmanuelaEvangelista $^{\ddagger}$ and \\ Fernando C.W. Rosas ${ }^{\S}$
}

†regon State University, Department of Fisheries and Wildlife, Corvallis, Oregon 97331, USA

‡Amazônia Onlus, comunidade Xixuaú, s/n, distrito rural, 69.373-000 Rorainópolis, RR, Brazil

${ }^{\S}$ Instituto Nacional de Pesquisas da Amazônia (INPA), Laboratório de Mamíferos Aquáticos (LMA), Caixa Postal 2223, 69080-971, Manaus, AM, Brazil

*Corresponding author: email Nicole.Duplaix@oregonstate.edu

\begin{abstract}
Giant otters, once targeted by the pelt trade to near extinction, are now legally protected and have made a comeback in some parts of their range. Our state of knowledge about the behavior and ecology of this apex predator has increased substantially since the first studies in the 1970s but remains incomplete. Negative anthropogenic pressures and conflicts affecting giant otters are intensifying and now take many forms, from extensive habitat loss and degradation, pollution, ecotourism with heavy impacts, to gold mining. We review the corpus of giant otter field research and findings since 1980 and discuss new findings and our shortfall of knowledge and their implications for the long-term conservation of the species.
\end{abstract}

Resumo: $\mathrm{O}$ abate de ariranhas para o comércio de suas peles no passado levou a espécie quase à extinção. Atualmente a caça à ariranha está proibida e algumas populaçóes têm dado sinais de recuperação em partes de sua distribuição. O conhecimento acerca do comportamento e ecologia deste predador de topo de cadeia aumentou substancialmente desde a realização do primeiro estudo com a espécie na década de 1970, mas permanece incompleto. Conflitos e pressóes antrópicas negativas têm se intensificado e abrangem desde a perda extensiva de habitat, poluição, ecoturismo pobremente manejado ou planejado, até a mineraçáo de ouro. Neste artigo nós revisamos o conhecimento atual gerado pelas pesquisas com ariranha após 1980 e discutimos as novas informaçóes, as deficiências de conhecimento ainda existentes e suas implicaçóes para a conservação desta espécie. 


\section{Introduction}

The giant otter (Pteronura brasiliensis (Zimmermann, 1780)), one of the larger carnivores of South America, is a primarily terrestrial mustelid that has become extremely well adapted to using an aquatic environment. This species is endangered in many parts of its range, although populations in the Amazon and Pantanal biomes seem stable and some have even increased over the last decades ${ }^{1}$. During the last century the main threat to the giant otter was the widespread commercial pelt trade carried out between 1940 and 1975. Today, widespread gold mining (and its attendant pollution), poaching, habitat loss and degradation, and poorly planned ecotourism threaten the species' future.

The IUCN Species Survival Commission declared the giant otter one of the ten most threatened mammals in 1972 and research was urgently needed to develop conservation measures (Anonymous, 1972). The first in-depth research, assembling comprehensive information on giant otter ecology and behavior in Suriname was published in 1980 (Duplaix, 1980). However, while that study increased our knowledge of the species, it raised many questions that required further investigation. Only after that, due to an increased awareness of the plight of the giant otter, several institutions started to promote research and identify the actions needed to plan the recovery of the species. In 1997, Carter and Rosas (1997) presented a review on the biology and conservation of the giant otter with emphasis on the systematics, morphology, physiology, distribution, and habitat use. Those authors also recommended elevating the conservation status of the giant otter in the IUCN Red Data Book from 'vulnerable' in 1990 to 'endangered'. In 2000 the IUCN recognized the threats facing the species and from that year on the giant otter was listed as 'endangered'. We present here a review of the current knowledge concerning the biology, ecology, behavior and conservation status of the giant otter.

\section{Anatomy and Physiology}

The giant otter is the largest member of the Lutrinae, the otter subfamily. The head is flattened, with very small round hairy ears. The muzzle is blunt with a haired rhinarium and stiff whiskers. The vibrissae are found above the eyebrows behind the eyes (supracilliary), and behind the curve of the mouth on the sides of the lower lips (Figure 1). The five toes on each foot have thick interdigital webbing that may be visible in tracks on a soft substrate. The tail is flattened and measures up to nearly half of the body length. The species ranges in color from brown when dry to a dark chocolate color when wet, and the lips, chin, throat and chest may be spotted with creamy white patches. The patch, however, can

${ }^{1}$ Groenendijk, J., Duplaix, N., Marmontel, M., Van Damme, P. and Schenck, C. (2015) Pteronura brasiliensis. The IUCN Red List of Threatened Species. Version 2015.2. <http://www.iucnredlist.org/>. Downloaded on June 112015 sometimes be restricted to a tiny one just below the chin or form a large creamy bib covering the throat and chest (Figure 2). The markings are present from birth and their size and shape vary between individuals providing an easy way to identify them (Duplaix, 1980; Carter and Rosas, 1997).

Neonates are born furred and with eyes closed and weigh 155-265g ( $\mathrm{n}=3$ ) (Hagenbeck and Wunnemann, 1991) on day 1. The mean length of newborn free-ranging giant otter cubs is $31.7 \pm 4.9 \mathrm{~cm}(\mathrm{n}=4)$ and the mean weight is $316.2 \pm 64.2 \mathrm{~g}$ ( $\mathrm{n}=4$ ) (Bozzetti et al., this volume). The mean length of two day-old cubs born in captivity on day 2 is $31-33.5 \mathrm{~cm}$ $(\mathrm{n}=5)$ and the mean weight is $161-230 \mathrm{~g}(\mathrm{n}=5)$ (Sykes-Gatz, 2005). Until recently the maximum giant otter body size mentioned in the literature was tentative and dimensions were said to vary between 1.5 to $2.4 \mathrm{~m}$ (Cabrera and Yepes, 1940; Harris, 1968; Duplaix, 1980; Santos, 1984). However, a body weight/length relationship study carried out by Rosas et al. $(2009 a)$ with captive otters revealed that adults measure typically between $1.5-1.8 \mathrm{~m}$ and weigh up to $30 \mathrm{~kg}$, and there is no significant difference between size and weight of giant otter males and females in the Amazon region. The mean total length of adult otters in captivity is $1.65 \mathrm{~m}$ (tail $65 \mathrm{~cm}$ ) and the mean weight is 22-26kg (Sykes-Gatz, 2005).

Two giant otter subspecies have been mentioned in the literature, one smaller (Pteronura brasiliensis paranensis) inhabiting the Paraná and Paraguay rivers (Pantanal biome), and one larger (Pteronura brasiliensis brasiliensis) inhabiting the Amazonas and Orinoco river basins (see Harris, 1968). According to researchers who are familiar with giant otters from both biomes (Amazon and Pantanal), animals from the Pantanal seem to be larger than those from the Amazon region. These findings, however, were based only on visual observations and a good number of captive and wild specimens must be properly measured according to the Standard Measurements of otters (see Appendix I) to resolve this issue. It must be noted, however, that dried skins and stuffed museum specimens may be longer than the live animal due to the skin stretching during the drying and preparation process.

Although general physiological data of giant otters are still scarce, some aspects of giant otter physiology are now available. According to Carter et al. (1999) the mean transit time of the food in giant otter digestive system is about three hours, indicating a high metabolic rate for the species. This information is especially important when anaesthetizing animals in order to help calculate the dosage of the anesthetics to be used.

According to Rosas et al. (2008a) normal hematological values of giant otters revealed that mean values of hemoglobin and packed cell volume (PCV) are $16.4 \pm 2.8 \mathrm{~g} / \mathrm{dl}$ and $50.7 \pm 7.8 \%$, respectively, and the mean values of red blood cells (RBC) and white blood cells (WBC) are $6.4 \pm 1.210^{6} / \mathrm{mm}^{3}$ and $5.4 \pm 1.910^{3} / \mathrm{mm}^{3}$. Regarding giant otter blood chemistry, the mean glucose, uric acid, creatinine and cholesterol values 

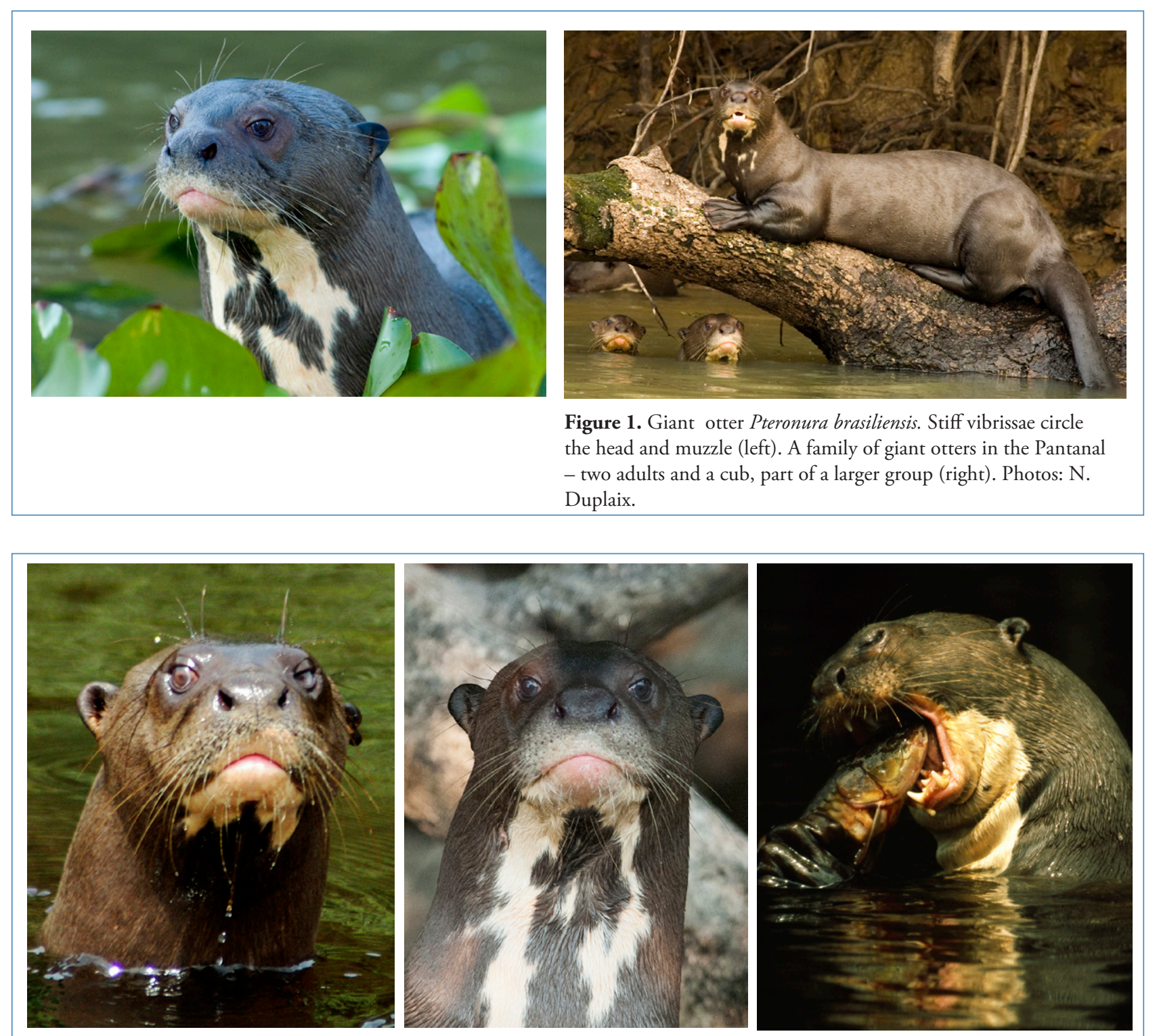

Figure 2. Natural markings on the giant otter's throat. Note the small creamy patch below the chin and the wounds to the eye and ear (left) and the large creamy patches across the neck and chest (middle). Otter with large chest patch is eating a Hoplias malabaricus (right). Photos: N. Duplaix

observed for the species were $100.7 \pm 42.0 \mathrm{mg} / \mathrm{dL}, 1.3 \pm 0.5 \mathrm{mg} /$ $\mathrm{dL}, \quad 1.8 \pm 0.9 \mathrm{mg} / \mathrm{dL}$ and $314.3 \pm 116.6 \mathrm{mg} / \mathrm{dL}$, respectively (Colares and Best, 1991; Rosas et al., 2008a).

After the review of morphological and physiological studies presented by Carter and Rosas (1997), few giant otter anatomic and physiological studies were carried out. However, Machado et al. (2002a, b, c) provided details on the anatomy of the aortic arch, lung lobulations, and the pattern of the formation of the cranial vena cava of giant otters with the aim of contributing to the comparative anatomy of vertebrates. Topographical anatomy of the medullar cone in giant otter is also described in Machado et al. (2009).

Based on the gross anatomy and histology of giant otter testes, Oliveira et al. (2011) suggest that giant otter males can present sexual quiescence with epididymes becoming aspermatic during the non-reproductive period, and turning into sexual activity during the female estrus when the reproductive season starts. This characteristic is very common in the seasonal breeding of monogamous species as the cost of producing spermatozoa is considerably high according to Kenagy and Trombulak (1986). However, a great number of male testes must be sampled throughout the year to confirm this hypothesis. It should also be noted that in captivity, giant otters produce litters all year around, with a peak from November through January (Sykes-Gatz, 2005) which may indicate that captive males do not undergo sexual quiescence.

\section{Phylogeny and Genetics}

Our views of the patterns of evolution of the Lutrinae have changed dramatically over the past 40 years thanks to the advent of molecular genetics and for this reason we will review recent findings in depth. Preliminary otter phylogenetic research 
was based on fossil evidence, comparative skull morphology and behavior ${ }^{2}$ (Duplaix, 1980; 1982; Van Zyll de Jong, 1972). Based on these early studies, the pattern of evolution of otters has proved to be a very rapid divergence into four well-defined branches: Pteronura, Enhydra, Aonyx-type otters, Lutra and Lontra-type otters. While the basic divergent lineages previously proposed for the otter genera, Aonyx, Lutra/Lontra originating in the Miocene proved accurate, it left the lineages of Lutrogale, Enhydra and Pteronura unclear. Recent molecular research has finally detailed the family tree of otters (Koepfli and Wayne,1998; Bininda-Emonds et al., 1999; Koepfli et al., 2008). Pteronura appears to be the first otter in the Lutrinae lineage and probably originated in Asia like the four New World Lontra species.

Garcia et al. (2007), analyzing the control region and the cytochrome $b$, cytochrome $c$ and oxidase subunit I genes of the mtDNA in several giant otter populations from the Amazon and Paraguay river basins, observed that $P$. brasiliensis populations seem to be geographically structured, but mtDNA data does not support the suggested subspecies division. The authors, however, recommend that a greater number of individuals should be analyzed from both biomes and that nuclear markers should also be applied to certify these results. Based on this suggestion, Pickles et al. (2011b) investigated mitochondrial genetic diversity and the evolutionary history of the species analyzing 70 genetic samples distributed among eight countries and four drainage basins. Their results also corroborate the data obtained by Garcia et al. (2007) concerning the lack of strong support to the division of giant otter subspecies. However, Pickles et al. (2011b) findings revealed four phylogroups: 1) Iténez and Uruá rivers (located in Bolivia and northwestern Brazilian Amazon, respectively), 2) Madre de Dios (Peru) and Madeira (Brazil) rivers, 3) Pantanal, and 4) Amazon, Orinoco and Guianas. Overall haplotype diversity was very high ( $h=0.93$ ) in all phylogroups with 41 haplotypes resolved, except in Pantanal $(h=0.44)$ where a single haplotype dominated $75 \%$ of all the sequences. The high degree of genetic diversity in $P$. brasiliensis contrasts with other Lutrinae species and also with the haplotype and nucleotide diversity previously found in giant otters by Garcia et al. (2007), who, however, analyzed samples from a more restricted distribution.

Such high level of mitochondrial genetic diversity was not expected given the demographic decline known to have occurred due to intensive hunting in the past. Pickles et al. (2011b) suggest that this may be partially explained by the giant otter longevity (up to 15 years recorded from free-ranging individuals) and a long generation time, reported to be seven years according to Groenendijk et al. (2005). Nevertheless, the lower haplotype and nucleotide diversity observed in the Pantanal phylogroup could be due to the more sustained level

${ }^{2}$ Davis, J.A. (1978) A classification of otters. Pages 14-33 in Duplaix, N. (Ed.) Proceedings of the First Working Meeting of the Otter Specialist Group 1977, Paramaribo, Suriname. of giant otter persecution in that region (Pickles et al., 2011b). The authors conclude that the phylogeographic pattern observed in giant otters might be the result of multiple drivers, as the molecular data suggests that no single paleoclimatic or paleoenvironmental event was likely to be responsible for the pattern. According to Groenendijk and Hajek (2006), the phylogeographic pattern is likely to have been preserved through isolation by distance and a male exogamous dispersal system.

Regarding the low haplotypic diversity observed in the Pantanal phylogroup, Pickles et al. (2011b) recommend special attention as this result may suggest that this phylogroup is the most fragile of them all. Pickles et al. (2012) also investigated patterns of population structure in those phylogeographic groups previously described and the data suggest a degree of reproductive isolation between the Iténez (Bolivia) population and the populations of northern South America.

However, data obtained by Pickles et al. (2012) presented little evidence of bottleneck despite the population collapse due to widespread hunting for pelts between 1940 and 1975 . According to the authors during this harvest period about 65000 giant otters were killed, corresponding to three or four generations of giant otters. Four reasons were presented by Pickles et al. (2012) to explain the lack of bottleneck signature and the retention of moderate genetic diversity: 1) the fur hunting period, while extensive, left multiple locally isolated pockets of otter packs, 2) the vagile nature of transient male giant otters maintained a degree of contact among dispersed packs, 3) reduced density effects following cessation of hunting may have encouraged recolonization of river systems from which the species was extirpated, and 4) the long generation time of the giant otter may have buffered the attrition of genetic diversity. Nevertheless, further work investigating contemporary and historical levels of genetic diversity in the eastern and southern parts of the otter's distribution, where the species is severely reduced, should be conducted to determine the actual effect of the past hunting pressures on the genetic diversity of $P$. brasiliensis (Pickles et al., 2012).

According to Franco-de-Sá et al. (2007) the diploid number of chromosomes in giant otters is $2 \mathrm{n}=38$, which is in agreement with more than $60 \%$ of the Mustelidae family members. However, although mustelid karyotypes are conserved in regard to diploid number they present considerable differences in chromosome structure, indicating that several rearrangements occurred during the evolution of this group. Thirty-six of the giant otter chromosomes were autosomes (14 metacentric +8 submetacentric +6 subtelocentric +8 acrocentric) and two sex chromosomes (Franco-de-Sá et al., 2007).

The fundamental number of autosomes was 64 , and the C-banding technique identified positive centromeric heterochromatin in all the chromosomes, with chromosomes 8,10 and 13 also showing telomeric heterochromatin. 


\section{Behavioral Repertoire}

The behavioral repertoire of the giant otter has been described in detail by several authors (Duplaix, 1980; 1982; Carter and Rosas, 1997; Staib, 2005) over the last four decades and will be quickly reviewed here, emphasizing only new research or lack of data. A more in-depth review article about giant otter behavior is forthcoming so we will only review a few aspects.

Locomotion: For a semi-aquatic species with heavy webbing, giant otters can move rapidly and far on land, up to $4 \mathrm{~km}$ or more to reach an oxbow lake for instance, and will climb near vertical banks of $4 \mathrm{~m}$ or more ${ }^{3}$ (Duplaix, 1980). Jumping across gaps appears more difficult and is avoided.

Aquatic locomotion takes many forms, from the slow, leisurely surface swim and dive that otters use when traveling through their territory to the very fast surface swimming when chasing a prey or another otter. Ribas and Mourão (2004) describe a noisy agonistic encounter of a resident group with a transient. Similar behavior was also observed in the Pantanal when a transient was chased by the group and attacked on shore (Duplaix, pers. obs.). During a chase group members are swimming close together, mostly on the surface keeping their heads above water, and screaming with the occasional loud contact whistle. After the attack the group resumes its more normal slow swimming pattern with low affiliative vocalizations.

Another swimming pattern is 'panic porpoising' (new term) which is seen only when otters have been persecuted and are easily alarmed. As soon as they see a human observer, even at a distance of 100 meters or more, they turn and swim away as fast as possible, porpoising in and out of the water with heavy splashing. This was observed in Peru and Suriname in gold mining areas where otters had been shot recently $y^{4}$

Comfort activities: Grooming and rubbing are frequently seen in otters as part of their daily activities and may be performed alone or involve other group members. Grooming and allogrooming activities usually take place immediately after feeding when the group comes ashore to rest. Grooming occurs on campsites or large logs and involves single individuals or includes other members of the group. Sometimes the group forms a tight cluster with both the cubs and subadults. 'Daisy chain grooming' (new term) is observed when more than two giant otters groom each another: one otter grooms another next to it that grooms the other otter next to it, etc. ${ }^{3}$. The otter at the end of the row may be grooming itself. When doing this, all the otters usually groom each other simultaneously, an individual pausing to look up and around only briefly.

${ }^{3}$ Duplaix, N. (2004) Guyana Giant Otter Project: 2002-2004 Research Results. Oceanic Society, San Francisco, California, USA. 44 pp. [available from http://www.giantotterresearch.com/articles/OCEANIC_SOCIETY_ Guyana_Project_Report_2002-2004.pdf]

${ }^{4}$ Duplaix, N. (2003) Giant Otter Final Report. WWF-Guianas Rapid River Bio-Assessments and Giant Otter Conservation Project FG-4O FY 2002. Paramaribo, Suriname. 119 pp. [available from http://www. giantotterresearch.com/articles/WWF_Giant_Otter_Report_PDFMini.pdf]
Scent marking: giant otters scent mark by depositing scats, urine and anal mucus on campsites, logs or boulders, as described by Duplaix (1980) and Carter and Rosas (1997). Leuchtenberger and Mourão (2009) observed that the time spent scent-marking ranged from 4.3 to 44.7 minutes and that alpha males marked more frequently than alpha females and covered the scents left by other members of the group with their own.

Vocal repertoire: The vocal repertoire of giant otters was first described by Duplaix (1980; 1982) who listed nine basic sounds with some variations based on observations and recordings. Machado (2004) described nine sounds from captive giant otters, of which four were not the same as ones described by Duplaix (1980) and the vocalizations showed significant differences in their acoustic structure. Bezerra et al. (2011) described five sounds emitted by giant otters in Jaú National Park in the Amazon. However, the authors did not record cub calls which may further add to the total vocal repertoire. Ribas and Mourão (2004) recorded a loud whistle during an agonistic encounter, mentioned above, which had not been described before for this species. Recently Leuchtenberger (2012) and Leuchtenberger et al. (2014) classified 15 sound types for giant otters living in the Pantanal, presenting combinations, gradations and acoustic components, which reflect the complexity of the communication system of this species. Munn and Knörnschild (2014) and Munn et al. (2014) described 22 distinct vocalizations produced by adults and 11 vocalizations of neonates and cubs in captivity and in the wild.

Reproductive behavior: After the rainy season, cubs are born just before or soon after the group returns to their dry season territory. Blastocyst implantation has not been reported in giant otters although it occurs in both the sea otter and the North American river otter (Kruuk, 2006). In captivity, estrus can occur every three months or immediately after the loss of a litter (Hagenbeck and Wunnemann, 1991) and litters are recorded for every month of the year with peaks from November through January (Brandstätter, 2011); but in the wild there is only one litter per year. False pregnancies are not uncommon in captivity (Rosas and De Mattos, 2003).

Litter size is 1-6 cubs with 3.2 being the mean litter size in captivity, based on 98 litters (Brandstätter, 2011; Corredor Londoño et al., 2006). Giant otters share a den with other members of the group except for a few days after parturition when the female has a separate birthing den or natal den (Duplaix, 1980; Rosas and De Mattos, 2003). Birthing dens are much smaller than the rearing dens where other group members may also be present. In Guyana, these temporary dens were well hidden under overhanging riparian vegetation and were not visited again after the female and her small cubs joined the group after a few weeks ${ }^{3}$. Such birthing dens were used again the following year unless they had collapsed but were not visited or used by the whole group 5 .

${ }^{5}$ D. McTurk, pers. comm., September 2004 
Both the alpha couple and subadults help rear cubs, alternating alloparental care babysitting duties throughout the day (Staib, 2005). However, the parents do not babysit their cubs in the den, leaving this task to other members of the group (alloparental care) (Rosas et al., 2009b).

Agonistic Behavior: Giant otters appear to avoid direct agonistic encounters with other groups most of the time ${ }^{3}$ (Duplaix, 1980; Carter and Rosas, 1997; Staib, 2005) although agonistic encounters occur during both the dry (Ribas and Mourão, 2004; Staib, 2005) and the wet seasons when groups move throughout their home range (McTurk and Spelman, 2005).

Apparently, different groups avoid agonistic encounters by scent-marking their use areas (Duplaix, 1980; Carter and Rosas, 1997; Leuchtenberger and Mourão, 2009; Evangelista and Rosas, 2011). Nevertheless, in spite of this use of keepout signals, intended to elicit escape and avoid responses by competitors, some agonistic encounters between giant otter groups and conspecific intruders, as well as infanticide, have been reported in the Pantanal (Schweizer, 1992; Mourão and Carvalho, 2001; Ribas and Mourão, 2004; Leuchtenberger and Mourão, 2009; Ribas, 2012), in Peru (Groenendijk et al., 2005) and in Guyana (McTurk and Spelman, 2005). When groups return to their territories at the beginning of the dry season, some group members exhibit head, foot, and neck wounds and scars (Figure 2), and some alpha group members do not return.

In Guyana, 28 giant otter cubs were hand-reared and 15 were rehabilitated back to the wild, eventually joined and were accepted into the resident wild giant otter groups living nearby and two bred successfully (McTurk and Spelman, 2005). According to these authors, five cubs or subadults were killed outright by resident giant otter groups in the vicinity who attacked and killed them on sight with a crushing bite to the head. In one case, a newly formed wild pair began interacting with four orphaned subadults, all joining together for a day on the river, with the orphans returning to the ranch at night. Later two of these subadults joined this new alpha pair and provided alloparenting care when five cubs were born but were driven out of the group when the pair had their second litter a year later ${ }^{3}$ (McTurk and Spelman, 2005).

Two juvenile $(1: 1)$ otters in Colombia were rehabilitated and released. They were both adopted by resident wild otter groups. The female juvenile was observed as the alpha female in a group five years later (Gómez et al., 1999; Gómez Serrano, 2003).

Group dynamics: Until recently, giant otter group composition was described as stable, consisting of a mated pair (alpha couple), with their subadult offspring and young of the year (Duplaix, 1980; Carter and Rosas, 1997). Recent studies have shown that both the alpha couple composition and subadult group fidelity may be more flexible than once thought (Evangelista, 2004; Leuchtenberger and Mourão, 2008). Newly formed pairs in a territory accepted nonrelated transient helpers and in more stable groups, subadults sometimes stayed with the group and did not disperse after two years (Leuchtenberger and Mourão, 2008).

When subadults or young adults leave the group and are on their own, mortality is a significant limiting factor, as they no longer have the 'security in numbers' of a group and ever-vigilant adults. These young adults, called 'transients' (Duplaix, 1980), must find both an attractive and empty territory as well as a mate as they wander up and down the river. The odds do not appear to be in their favor unless there are other breeding groups present in the watershed or a minimum otter population density. While mortality data are unavailable for transients, many do not re-appear as adult pairs in such well-studied areas as Karanambo and the Pantanal (McTurk and Spelman, 2005; Leuchtenberger and Mourão, 2008). So we must ask ourselves: Are giant otter populations viable long-term in areas where human pressures on the rivers are increasing?

From our surveys in Guyana and Suriname, we concluded that in larger watersheds like the upper Coppename River in Suriname and the upper reaches of the Rewa and Kitaro rivers in Guyana, both still pristine habitats, giant otters will continue to survive for many years if they remain isolated and largely undisturbed ${ }^{3,4}$ (Pickles et al., 2011a). It is in the smaller watersheds that the future long-term presence of otters is uncertain with human impacts rapidly mounting (dams upstream, fishing, logging activities) and where otter habitats are limited due the size of the available habitat.

Colonizing a vacant river or re-colonizing vacant portions of a disturbed river is not straightforward. Once giant otters have abandoned a river (or, worse, a watershed) or been extirpated by hunters this creates a void and an opportunity for transient otters seeking to establish territories of their own. It is unlikely that such young, inexperienced animals, would find an adjacent empty river or watershed that might involve long and dangerous overland exploration. By exploring the river they know, their chances of success appear to be higher than setting out overland to explore unknown adjacent rivers.

In Peru, Schenk et al. (2002) and Frank et al. (2002) created a model to test the likelihood of a transient otter meeting a mate at the right time in the right place and finding an empty territory. First, there must be a reasonable number of transients present in a given river looking for mates each year. Second, each group must have a minimum number of cubs surviving to subadulthood in order to provide a minimum number of transients each year. High cub mortality, due to predation, disease or collecting by humans, will have a direct effect on the number of transients that will set out on their own.

This 'colonization potential' by transients is clearly the vital key to the long-term viability or collapse of a giant otter population on any given river in the Guianas just as it is in Brazil and Peru. If the population numbers are high enough to withstand accidental loss of cubs or transients, all is well and the resident population may even expand. The more resident otter groups breeding each year, the more young 
adults must leave their group. The more transients on the river each year looking for a mate, the higher the probability of success and the quicker a territory is created or re-occupied. If, through attrition, pollution or accidental loss, the otter population number falls below a certain critical level, or if the population becomes too isolated geographically from the next nearest group of resident otters, the transients will not be able to reach it in time before the wet season dispersal, and the collapse of the population is inevitable in this situation because there is minimal likelihood that transients will meet or find mates. These 'colonization potential' factors and shortcomings should be carefully considered before a giant otter reintroduction program is attempted in an 'empty' river system.

Establishing the minimum number of transients needed each year to insure the long-term viability of a giant otter population in a given watershed is difficult to determine, as it probably varies with the type of river system and how many potentially attractive empty territories are available, and how far they are apart from each other. The most important factor in ensuring survivability is preventing increased giant otter mortality due to anthropogenic factors that may trigger the irreversible population collapse of this endangered species in one river system after the other.

Social behavior: Giant otters are very social animals, living in groups with up to 16 individuals. Until recently it was believed that the groups consisted of a breeding pair (alpha couple) and its offspring from the last 2 or 3 years (Duplaix, 1980; Carter and Rosas, 1997; Leuchtenberger and Mourão, 2008). Nevertheless, a molecular study carried out by Ribas (2012) with giant otters in the Brazilian Pantanal revealed that this is not a general rule. Although some group members are sons and daughters of the alpha pair, the author found giant otter groups where the members were not related with the alpha pair, but also they were not related among themselves. This brings new light to the group composition and group dynamics of giant otters. However, relatives or not, the whole group defends their territory together, but cooperative fishing is not very common, although not completely absent.

As mentioned above, alloparental care has been recorded in this species but it is not mandatory (Rosas et al., 2009b). The presence of baby-sitters in the dens during the day is usually related to an imminent threat in the vicinity of the den. According to Rosas et al. (2009b) giant otters seem to remain between obligate cooperators and non-cooperative breeding species, and the precise function of the baby-sitters needs further investigation, as some subadults seem to remain for long periods in the group and are potentially lifelong baby-sitters, while others disperse when they reach sexual maturity. In the Pantanal, a female left her group and became a transient at the age of ten months (Leuchtenberger and Mourão, 2008).

\section{Ecology and Distribution}

Habitat: Giant otters can be found in clear and muddy waters. However, as visual predators, the black and clear water rivers seem to be their preferable habitat (Duplaix, 1980; Rosas et al., 1999; Van Damme et al., 2002). Even when living in white water environments, the species shows a preference for the clearer water of oxbow lakes and larger forest creeks instead of the main river $^{6}$ (Duplaix, 1980). Water transparency is an important environmental factor affecting habitat use and distribution of giant otters, although the species shows some degree of flexibility, depending on resource availability and environmental restrictions. For instance, in Guyana and in the Pixaim River in the Pantanal the key territories inhabited by the species have muddy waters loaded with sediment $(\mathrm{N}$. Duplaix, pers. obs.). Wide rivers with strong current are not the main habitat for giant otters although they may be used for transit as they are in the upper Coppename River in Suriname ${ }^{4}$ (Duplaix, 1980). The species, instead, prefers creeks and lakes, with shallower waters. A number of authors have found giant otter living and fishing in water bodies with a depth ranging from $0.2 \mathrm{~m}$ to a maximum of seven meters ${ }^{6}$ (Staib, 2005; Carrera-Ubidia, 2006; Evangelista and Rosas, 2011) with no relation between intensity of use and depth in $\mathrm{Peru}^{6}$. On the other hand, in the Central Amazon, Lima et al. (2012) found that the animals avoid using water bodies < $1 \mathrm{~m}$ deep, and suggest that this is due to the fact that shallow waters are probably less suitable to higher fish concentrations due to lower oxygen concentrations.

In the past, hydroelectric dams were considered negative geographical barriers isolating populations of giant otters (Rosas et al., 1991). Recent studies however have shown that the changes in the hydrological inundation pulse, modifications in the ichthyofauna, and the permanent lentic condition created by the Balbina dam may not offer a threat to giant otters (Rosas et al., 2007). According to the authors, at least two conditions are required to enable the regular presence of the species in similar environments, i.e. (1) the presence of otters in the area before dam construction and (2) absence or sparse human communities around the reservoir as is the case in the Balbina Reservoir (Rosas et al., 2007; Cabral et al., 2010). However, major dam projects often cause a heavy sedimentation build-up and disrupt fish migration cycles. Large dams such as those planned in the Amazon basin will attract increased human activities, roads, and even new cities which are incompatible with ideal otter habitats.

Authors agree that foraging areas in water and shelter areas on land are the main key factors in giant otter habitat choice. Easy access to forest creeks and shallow areas with secure food availability will influence its habitat preference as well as refuge availability (Lima et al., 2012) and the level of anthropogenic threats (Dauphine, 2001).

${ }^{6}$ Schenck, C. (1999) Lobo de Rio (Pteronura brasiliensis). Presencia, uso del hábitat y protección en el Perú. GTZ/INRENA, Lima, Perú. 
Home range and movements: Giant otters are territorial and information on their vital areas comes from a number of studies, most of them conducted during the dry season. In Suriname and in the northern Brazilian Amazon the estimation of minimum giant otter home range size varied from two to $12 \mathrm{~km}$ and from 4.6 to 10.4 linear $\mathrm{km}$ of small black water creeks, respectively (Duplaix, 1980; Laidler, 1984; Evangelista and Rosas, 2011). Similar results were found in the Pantanal, where territories show a mean extension of $11.4 \mathrm{~km}$ (from 5.2 to $19.7 \mathrm{~km}$ ) and an average distance between the centers of the territories of neighboring groups of $10.8 \mathrm{~km}$ (from 2.2 to $17.2 \mathrm{~km}$ ) (Leuchtenberger and Mourão, 2008).

However, larger vital areas have been found in other studies. In Guyana, the home range of one group of giant otters was estimated to be $20 \mathrm{~km}^{2}$ of lake habitat, with a large territory size of $5 \mathrm{~km}^{2}$ (Laidler, 1984). In southeastern Peru, giant otter home ranges vary from 0.55 to $1.08 \mathrm{~km}^{2}$, typically including one or two oxbow lakes, several streams or swamp areas, and a stretch of river (Staib, 2005). In Ecuador they can be even larger, ranging from 0.45 to $2.70 \mathrm{~km}^{2}$ (Utreras et al., 2005) and in areas of high human disturbance, annual home range may correspond to one entire watershed, measuring $50 \mathrm{~km}^{2}$ (Carrera-Ubidia, 2006). All these estimates were based on visual observations of the animals or of their signs and therefore are subject to bias as some habitats used by giant otters include llanos, wetlands and small creeks that are extremely difficult to survey and can easily contribute to underestimating the species' vital areas.

A giant otter group monitored for 12 months via radiotelemetry in the Amazon-Cerrado ecotone, in northern Brazil, revealed a home range of $16.25 \mathrm{~km}^{2}$ (De Almeida Jácomo et al., 2009) ${ }^{7}$. However, a lack of standardization in data collection methods and data analysis from one study to another compels us to interpret these results with caution. Recent studies in the Pantanal, using the k-LoCoh (98\%) method, indicated that the home range sizes during the wet season $\left(3.6-7.9 \mathrm{~km}^{2}\right)$ were often much larger than during the dry season $\left(0.1-2.3 \mathrm{~km}^{2}\right)$ (Leuchtenberger et al., 2013).

In principle, the type of habitat seems to affect the size of giant otters' home range, which appears to decrease as the population density increases. In fact, the ecological giant otter population densities appear to be higher in Suriname and in the northern Brazilian Amazon where the estimation of minimum giant otters home ranges varied from 2 to $32 \mathrm{~km}$ and from 4.6 to 10.4 linear $\mathrm{km}$ of small black water creeks, respectively (Duplaix, 1980; Evangelista and Rosas, 2011) when compared to otter densities in Guyana and Peru (1/5.6 and 1/5.7 animal for $\mathrm{km})^{3,6}$. Based on these varied findings and as a general rule, there does not seem to be a linear

${ }^{7}$ De Almeida Jácomo, A.T., Furtado, M.M., Rosas, F.C.W., Correia da Silva, L.C.L., Sollmann, R., Torres, N.M. and Silveira, L. (2009) Giant otter radio-telemetry in Cantâo State Park, Northern Brazil. Page 256 in Carnivore Conference - Carnivore Conservation in a Changing World, 2009. Denver, Colorado, USA. correlation between group size and home range or territory sizes (Utreras et al., 2005; Leuchtenberger and Mourão, 2008; Evangelista and Rosas, 2011) although larger territories have more latrines and scent marks (Leuchtenberger and Mourão, 2008). Once data collection methods have been standardized, otter population densities may be better understood and compared.

Food availability and spatial structure of the habitat are more important causal factors influencing the giant otter's home range size, through accessibility to good fishing areas and suitable riparian areas for campsites and dens (Fig. 3C, D). For instance, in Peru these factors produce a significant relationship between group size and oxbow lake size, with larger giant otter groups tending to inhabit the largest lakes ${ }^{6}$ (Groenendijk and Hajek, 2006). It is possible that the increase (Laidler, 1984) or contraction (Evangelista and Rosas, 2011) of home ranges is linked to the development stages of the litter and that groups tend to stay closer to their core area when the cubs are young ${ }^{3}$ (Leuchtenberger et al., 2013).

Territory size may also be related to defense ability and to the pressure exercised by the neighboring groups, which may change in response to seasonal variations in the river's water level and has been observed in the Pantanal (Leuchtenberger, 2012). Home ranges seem to strongly overlap in some regions ${ }^{3}$ (Duplaix, 1980; Laidler, 1984), partially in others (Utreras et al., 2005; Groenendijk and Hajek, 2006; Leuchtenberger and Mourão, 2008; Evangelista and Rosas, 2011; Leuchtenberger, 2012), particularly in areas located near to the mouth of the river (Leuchtenberger and Mourão, 2008; Evangelista, pers. obs.) and not at all in oxbow lake environments ${ }^{6}$ (Staib, 2005).

In seasonally flooded areas the space used by giant otters is vulnerable to water level oscillations and pulses. Little is known about the intensity and extent to which giant otter groups use flooded forests areas during the rainy season, when movements seem regulated by the dispersal of the spawning fish, the habitat availability and the depth of the water ${ }^{3}$ (Duplaix, 1980; Utreras et al., 2005). Duplaix (1980) speculated that each giant otter group in her study area in Suriname defended its territory throughout the dry season and abandoned it during the rainy season, when each group followed the fish into the flooded forests. The aforementionned studies have shown that a group can increase its home range up to 13 times during the high water season in Ecuador (Utreras et al., 2005) and up to 59 times in the Pantanal (Leuchtenberger et al., 2013), thereby expanding the usual territory to which the group returns, regularly and predictably, at the start of the next dry season (Evangelista and Rosas, 2011), while others groups disperse further (Carrera-Ubidia, 2006).

On the other hand, in southeastern Peru no difference was found between wet and dry season home ranges of giant otters $^{6}$ (Staib, 2005), suggesting that the spatial and temporal dynamics of its habitat use are variable and strongly influenced by complex interactions between hydrologic patterns and habitat features. Sliding and exchanging territories have been reported in 

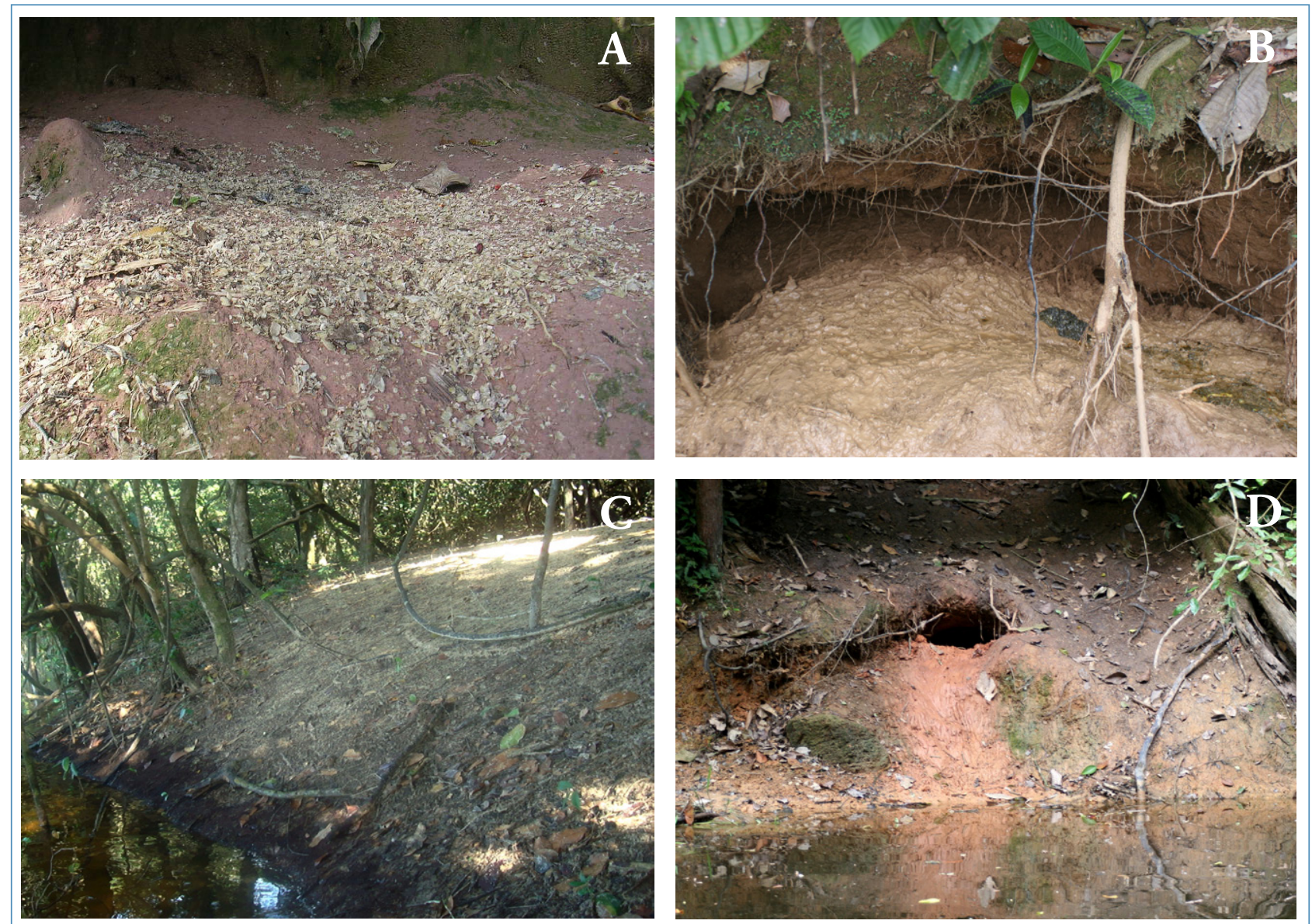

Figure 3. Giant otter communal latrine not in use $(A)$ and in use (B), campsite (C) and den in use (D) in Balbina hydroelectric reservoir, Brazil. Photos: F. Rosas

a number of recent studies including hostile take-overs, and in only a few cases were they connected to the favorable condition of an area vacated by the group in residence (Duplaix, 1980; Staib, 2005; Leuchtenberger and Mourão, 2008; Evangelista and Rosas, 2011).

Within their home range giant otters build dens (Fig. 3D) in the banks of rivers and lakes and maintain various campsites (Fig. 3C), both extensively described in Duplaix (1980), Carter and Rosas (1997) and in Groenendijk et al. (2005). According to Duplaix (1980), vegetation cover, shape, structure, accessibility and low sloping banks seem to influence the giant otter's habitat selection for shelters, although Schenck and Staib (2002) did not find any statistical relation between these habitat parameters and giant otter density in Peru. However, Lima et al. (2012) found that the species is site-selective, preferentially building dens and campsites at $<2 \mathrm{~m}$ from the water, on slopes $<45^{\circ}$. The authors conclude that the physical components of habitats, their vulnerability to flooding and erosion and the amplitude of the water level fluctuations can affect the availability of shelters and therefore the animals tend to avoid excavating dens in such unstable banks (Lima et al., 2012). In Guyana and Peru, where low sloping banks are scarce, they do dig dens in high clay banks but few last more than a year ${ }^{3}$ (Staib, 2005).
Diet: Direct observation and scat analyses in various regions of the geographical distribution of giant otters have revealed that fish constitute the majority of their diet. Preferred fish are from the orders Characiformes, Perciformes and Siluriformes (Duplaix, 1980; Rosas et al., 1999; Staib, 2005; Cabral et al., 2010). Although fish comprise the main prey item, other prey such as crustaceans, mollusks, birds, reptiles, amphibians and small mammals are mentioned in the literature ${ }^{6}$ (Duplaix, 1980; Schweizer, 1992; Rosas et al., 1999; Staib, 2005; Cabral et al., 2010; Rosas-Ribeiro et al., 2012), including small anacondas, turtles and caimans (Kruuk, 2006; Ribas et al., 2012). Captive giant otters eat on average $10 \%$ of their body weight per day (Carter et al., 1999) and wild adults may consume around 3-4kg of fish per day (Duplaix, 1980; Staib and Schenck, 1994; Cabral et al., 2010). Preferred fish size range from $7-25 \mathrm{~cm}$ up to $30 \mathrm{~cm}$ in length depending on the fish species, although otters were seen catching prey up to $100 \mathrm{~cm}$, causing great excitement in the group $^{3}$ (Duplaix, 1980; Staib, 2005).

When data from different areas are compared, some regional differences among the preferred prey consumed by giant otters emerge. This is probably due to the huge diversity of the South American ichthyofauna, which may influence the availability and vulnerability of fish species. Procedural 
limits in prey identification may also be a factor, in fact when prey comparisons from different areas are pushed to a lower taxonomical level even more regional differences emerge.

The fish families most frequently found in giant otters diet include Cichlidae, Erythrinidae, Characidae and Anostomidae followed by Prochilodontidae, Auchenipteridae, Doradidae, Loricariidae, Pimelodidae, Gymnotidae and Sciaenidae (Duplaix, 1980; Rosas et al., 1999; Davenport, 2008; Cabral et al., 2010; Rosas-Ribeiro et al., 2012). The family Erythrinidae (represented by trahiras, Hoplias malabaricus) is frequently found in the giant otters diet in small rivers and creeks (Duplaix, 1980; Rosas et al., 1999; Davenport, 2008; Cabral et al., 2010; Rosas-Ribeiro et al., 2012). Cabral et al. (2010) mention that in Balbina reservoir the presence of piranhas occurred at twice the level reported in other studies, even though the subfamily Serrasalminae is relatively frequently identified in scats from different regions (Rosas et al., 1999; Cabral et al., 2010; Rosas-Ribeiro et al., 2012). On the other hand, scat analysis in Peru found that two species in particular are preferred - Prochilodus nigricans (Prochilodontidae) and Satanoperca jurupari (Cichlidae) - although the precise reason for this preference over other species such as the abundant piranha is not clear ${ }^{6,8}$. Nevertheless Davenport (2008) found, through visual observations, that piranhas are important components in the otters' diet throughout the year in Peru.

The common denominator among the fish prey most represented in giant otter diet is that they inhabit both in rivers and lakes, shallows near the bank, with submerged branches and trunks present. Most of the preferred fish species have sedentary lifestyles and are territorial and ambush-hunters. Authors agree that this behavior, along with the higher visibility of these microhabitats, probably makes hunting along the shoreline a preferred method and less costly in terms of energy expenditure (Duplaix, 1980; Rosas et al., 1999; Groenendijk and Hajek, 2006). From an otter's perspective, it seems advantageous to chase a bottomdwelling fish like Hoplias sp., or small platted catfish that can be flushed and cornered rather than mid-column fish living in schools like Serrasalmus sp. However, if the otters are hunting in groups they will chase and capture Serralsamus sp. Moreover, shoreline hunting appears safer for young cubs as suggested by Staib (2005) and Davenport (2008). Both these authors noticed that giant otters in Peru hunt with different intensity and different hunting methods in different areas according to the presence or absence of cubs, in order to accommodate their limited swimming ability and poor handling skills whereas Rosas et al. (1999) and Cabral et al. (2010) did not find any difference in the diet of giant otters with or without cubs. Fishing in open, deep water in oxbow lakes (up to seven meters deep), is also a common giant

${ }^{8}$ Groenendijk, J. (1998) A Review of the Distribution and Conservation Status of the Giant Otter (Pteronura brasiliensis), with Special Emphasis on the Guayana Shield Region. Report for the International Fund for Animal Welfare by the Netherlands Committee for IUCN. 55 pp. otter technique but it targets different groups of fish and is performed less frequently (Staib, 2005).

There are different views in the literature in regard to giant otter feeding strategies. According to Schenck ${ }^{6}$ and Staib (2005) giant otters are selective predators. In spite of the high local fish biodiversity found by these authors in Peruvian oxbow lakes (200 species of fish), giant otters cover $70 \%$ of their food requirement by feeding on only two species, with eight species forming $97 \%$ of their diet. However in Peruvian rivers such as the Palma Real, where there is similar species richness but less fish density, giant otters consume a much broader spectrum of available prey (Groenendijk and Hajek, 2006).

Duplaix (1980) first described Pteronura as an opportunistic predator exploiting available prey categories as also supported by other authors (Schweizer, 1992; Carter and Rosas, 1997; Carrera-Ubidia, 2006). Variation in the frequency of occurrence of some prey items in the diet of the giant otter throughout the hydrological cycle have been observed in different areas (Davenport, 2008; Cabral et al., 2010). According to Cabral et al. (2010), giant otters present an opportunistic feeding behavior during the high water season, when fish disperse throughout large areas in the flooded forest, becoming more difficult for giant otters to catch, and turn to a selective feeding behavior during the low water season when preys become restricted to the main river channels and to perennial water bodies. Low oxygen conditions as well as the reproductive behavior of year-round residents may make fish species more susceptible to the otters' hunting methods in certain periods (Davenport, 2008).

Top predators like giant otters will probably catch fish infested with parasites or with some other pathology quickly as they are more vulnerable and present an easy prey. By removing these weaker individuals, giant otters will help maintain the health of the fish population and the equilibrium of the whole ecosystem. Otters are both specialized enough in exploiting shallow water fish species and flexible enough to also hunt very successfully in deeper waters with a fish capture rate more than twice as high as that obtained in shallow water (Staib, 2005). They are both selective and opportunistic predators, eating prey in relation to their availability in the environment and selecting them according to their size, behavior and low catch and handling costs. However, in ideal conditions, like during the low water period, when fish numbers are more concentrated, otters will show preferences for other favored fish species.

Distribution and abundance: The extent of the giant otter distribution and population sizes in most parts of the species' range is uncertain. It seems that its range has decreased considerably during the last century. However, as the exact extent of the remaining area inhabited by the species remains largely unsurveyed, researchers are unable to assess the magnitude of this decrease (Reuther, 2004). Endemic to South America, the giant otter has a vast and heterogeneous 
distribution range, which includes highly diverse habitats, some of these extremely isolated and inaccessible. The northern extent of its range borders does not include the Caribbean Sea, and the southern extent reaches Argentina, although Argentine and Uruguayan populations are thought to be extinct ${ }^{1}$. The species is not found in Chile but it is reported to occur in Bolivia, Brazil, Colombia, Ecuador, French Guiana, Guyana, Paraguay, Peru, Suriname and Venezuela ${ }^{8}$ (Carter and Rosas, 1997; Duplaix et al., 2008). Since the first long-term giant otter study in Suriname between 1976 and 1978 (Duplaix, 1980), distribution surveys and population censuses have been conducted in several countries of the giant otter's former and present distribution range (Groenendijk et al., 2005). However, information is patchy throughout South America and many remote areas have not been surveyed recently. Comprehensive reviews of giant otter distribution have been compiled by Carter and Rosas (1997) and updated by Groenendijk $\mathrm{k}^{8}$. In this section we provide only a brief outline.

The current total wild population is unknown and further surveys are required to define its parameters. It is likely that the majority of the animals are found in the Brazilian Amazon and the regions immediately bordering this area in the Guianas (Kruuk, 2006). Current population trends are also unknown. Giant otter populations are gradually increasing in some parts of their range (Bolivia, Brazilian Amazon, Pantanal) returning to watersheds where they have been absent for many years (Peru), but in other areas they are thought to be declining due to new or increased pressures such as habitat loss and the effects of gold mining and mercury pollution (Guyana, French Guiana, Suriname). The country-by-country summary of the current situation of giant otter populations reported here is based on published accounts, field reports, and information provided by colleagues during the XIV Working Meeting of Experts in Aquatic Mammals of South America (Zambrana and Van Damme, 2011).

Argentina: Giant otters appear to be now absent in northern Argentina (Chehébar, 1991), however, a decadesold skull of a giant otter was recovered in the Corrientes Province, and confirms the historical presence of the species 9 (Parera, 1992; Beccaceci and Waller, 2000).

Bolivia: Populations in gradual recovery in the Beni, Iténez and Paraguay river basins, no signs of recovery in the Mamoré River basin. Total population estimated between 500 and 1500 individuals. More detailed results can be obtained in Van Damme et al. (2002).

Brazil: Information is limited if compared to the wide extent of the country, which covers more than three quarters of the giant otter range. Carter and Rosas (1997) describe several river basins and Rosas et al. (2008b) mention several protected areas where the species occurs. Populations are

${ }^{9}$ Parera, A. and Bosso, A. (1991) Mustélidos acuáticos del rio Iguazú superior. Fucema. Informe inédito. $35 \mathrm{pp}$. stable and possibly recovering in some parts of the Amazon (Rosas et al., 2008b). The population in the Pantanal seems to be in good condition, with estimates of more than 3000 individuals (Tomás et al., this volume) and signs of reaching carrying capacity in some areas (Leuchtenberger and Mourão, 2008; Ribas et al., 2012). Recent records of giant otter presence include the lower Purus River in the state of Amazonas (Rosas et al., 2003), some black water tributaries of the Madeira River (F. Rosas, pers. obs.) and the Amaná Lake (Lima et al., 2012); the lower Branco River in the state of Roraima (Evangelista and Tosi, this volume); and the Xingu River in the state of Pará (F. Rosas, pers. obs.).

Colombia: Presence is recorded in the Amazonía (department of Amazonas) and Orinoquía regions (departments of Arauca, Vaupés and Vichada) (Gómez and Jorgenson, 1999). Recent records come from the department of Casanare (Javier Diaz and Sanchez, 2002).

Ecuador: Extinct in the northern part of Ecuadorian Amazonia and only present in the most remote areas of the eastern lowlands: in the Yasuní National Park and the Pastaza, Morona and Zamora river basins (Utreras and Araya, 2002).

French Guiana: Wide distribution in the country but signs of decline of populations in areas with high human impact and/or heavy gold-mining activities ${ }^{10}$. Number of individuals in each group decreased compared to data collected five years before (Jacques et al., 2001).

Guyana: Stable populations in southern Guyana (Rupununi, Rewa, Kuyuni, and high Essequibo rivers) $)^{3,4}$ (Roopsind, 2002; Pickles et al., 2011a). Populations present in small tributaries and wooded areas. Declining populations in Cuyuni, Mazaruni, Essequibo and Demerana rivers. Recent sightings on the Potaro Plateau, western Guyana and Sipu River. Abundant along the Kuyuwini River (Barnett et al., 2000).

Paraguay: Current distribution restricted to the upper Paraguay River basin, from Carmelo Peralta to the northern border ${ }^{11}$.

Peru: Populations in gradual recovery in the Samiria and Yanayacu river basins in Samiria National Reserve in Yavari and Yavari-Mirin rivers (Recharte and Bodmer, 2010). Recovering populations occur in Reserved Zone Gueppi and stable populations in Manu National Park, and in some lakes in the Tambopata River. Critically low population levels exist in Yanesha (Schenk and Staib, 1994; Groenendijk and Hajek, 2006).

Suriname: Stable populations in the Central Suriname Nature Reserve (11\% of the country) in the upper Coppename River basin, upper Corantyne River and Lucie River. Declining or absent populations in Nickerie, Commewijne,

${ }^{10}$ Delcourt, B., Denis, T., Feuillet, G., Gratiot, J., Pineau, K., Puthon, A., Salaud, J., Delaval, M. and De Thoisy, B. (2006) Suivi des populations chez la loutre géante: aide à la conservation d'une espèce emblématique des cours d'eaux amazoniens. Association Kwata. Cayenne, Guiane. 21 pp.

${ }^{11}$ J. Groenendijk, pers. comm., 28 August 2013 
Maronie, Kabalebo and lower Corantyne rivers. Populations present in small tributaries and forested areas. More detailed results can be found in Duplaix ${ }^{4}$.

Venezuela: fragmented populations reported northeast of Merida mountains and in the bioregions of Maracaibo Lake, Los Llanos, Sistema Deltaico, Orinoquía and Amazonía (Lewis et al., 1997) ${ }^{11}$.

Main threats to the species: In the past, the main threat to giant otters was the international commercial fur trade (Rosas, 2004; Rosas et al., 2008b). Nowadays, however, the species is legally protected in all the countries throughout its distribution by CITES and to our knowledge there is no significant commercial trade, although some skins might still be exported illegally.

Giant otters are gradually increasing in number in some parts of their range and are returning to areas where they have been absent for many years. At the same time human population is increasing as well; in the Brazilian region alone the human population increased from 6 million in 1960 to 25 million in 2010 (Davidson et al., 2012). The coexistence of these two species should not prove impossible, after all humans and giant otters have inhabited the same regions for many thousands of years. However, the expansion of the human footprint during the past decades has been unprecedented; the colonization of new regions through intensive exploitation of natural resources has affected the environmental conditions of formerly pristine areas, reducing the water quality and riparian quality of the rivers. Destruction of forests, leading to soil erosion and decrease of prey abundance as well as the dredging of rivers, streams and creeks for boat transportation and gold mining, the pollution of water by fertilizers and fuel, and over-fishing are all related to human colonization activities. Accelerating habitat destruction and degradation throughout the giant otter's range is therefore considered the greatest threat to the species (Carter and Rosas, 1997; Duplaix et al., 2008).

Canine diseases such as parvovirus and distemper transferred through the domestic stock are, as yet, an incalculable threat ${ }^{6}$. New menaces are represented by conflict with fishermen, poorly managed tourism activities and climate change. Among all those factors, the giant otter's behavior may not help shield it from persecution. Large diurnal groups of inquisitive and noisy animals make an easy target for a poacher or an irate fisherman. Young cubs peeking out of a den while the parents are away make them particularly vulnerable to kidnapping by humans.

Hunting: Although commercial hunting, instigated by the pelt industry, decimated giant otter populations in past decades (1940-1975), the current effect of direct capture or killing of otters is minor today compared to the past. Yet poaching and trapping have been reported almost everywhere in the otter's distribution range, either related to the illegal fur trade reported in Ecuador (Utreras and Araya, 2002), Bolivia (Zambrana and Van Damme, 2011), or to sell live animals in Colombia (Zambrana and Van Damme, 2011) and Brazil (Alves and Andriolo, 2010). Otters may be shot 'for fun' as in Peru $^{8}$, Venezuela ${ }^{12}$ and Suriname ${ }^{4}$. The capture of cubs as pets has been recorded in Guyana (McTurk and Spelman, 2005; Zambrana and Van Damme, 2011) and Brazil (Rosas et al., 2008b; Lima and Marmontel, 2011).

The emerging conflict with fisheries has motivated the killing of giant otters in Brazil (Rosas-Ribeiro et al., 2012), Guyana $^{3}$ and French Guiana ${ }^{8}$. There are no official records for these killings or for the dependent cubs killed with the death of their parents. A fisherman in southern Peru deliberately killed all the giant otters he could find along the entire length of a river $^{13}$. Though the numbers may be low, incidental hunting can contribute significantly to the extinction of locally isolated populations that already face other threats, such as habitat degradation and water contamination. Re-colonization of a watershed is known to occur slowly. Frank et al. (2002) and Schenck et al. (2002) have shown that once giant otters have abandoned a river basin or have been extirpated by hunters this creates a gap that diminishes the population's chance of long term survival.

Conflict with fishermen: Giant otters are blamed for declining fish stocks, as they are perceived to be competing with fishermen for the same species. The same is true for otter species elsewhere in the world. As fishing is an important subsistence and commercial activity in most parts of the giant otters' range, recent studies have evaluated the potential conflict with the species. Conclusions have shown that giant otters have little effect on fisheries for the overall overlap between otter prey species and those of commercial interest is small, hence proving a minimal competition for fish (RosasRibeiro et al., 2012). In spite of that, informal interviews with fishermen have shown that giant otters are considered a competitor for fish in northeastern Peru (Recharte et al., 2008) and in the Brazilian Amazon (Rosas-Ribeiro et al., 2012; Lasmar et al., 2013; Evangelista and Tosi, this volume). Interestingly, when more structured interviews are compared with diet analysis, it emerges that the local community's perspective of the feeding preferences of the otters may be incorrect (Roopsind, 2002; Rosas-Ribeiro et al., 2012).

Fishermen-giant otter conflicts were recently analyzed by Rosas-Ribeiro et al. (2012) in the Uacari Reserve (Brazilian Amazon), where giant otters are accused of interfering with fisheries by eating fish (predation), scaring fish away (local interference), and damaging fishing equipment (direct interference). Their study found that both the overlap between fish species consumed by otters and humans, and the giant otter presence during the human fishing activity was low $(0.34 \%$ and $9.5 \%$ respectively) and did not significantly

\footnotetext{
${ }^{12}$ Mondolfi, E. and Trebbau, P. (1978) Distribution and status of the giant otter (Pteronura brasiliensis) in Venezuela. Pages 44-47 in Duplaix, N. (Ed.) Proceedings, First Working Meeting of the Otter Specialist Group, 1977, Paramaribo, Suriname

${ }^{13}$ Rob Williams, pers. comm., 2012
} 
reduce the fishery captures. Moreover the conflict was restricted to the high water period, when both species tend to be more generalists and the income from the fisheries decreases. However, in regions of higher anthropogenic pressure the picture might be different. According to CarreraUbidia (2006), overlap between giant otter and human diets in the lower Yasuni Basin (Ecuador) may vary between $55-82 \%$ when fish availability and dietary preferences are included or excluded, respectively. Therefore remaining populations of giant otters are particularly threatened where human colonization exposes large expanses of habitat to the invasion of settlers, who rely on fish as their main protein source and often use more invasive fishing methods, such as dynamite and small-mesh nets spanning creek entrances.

Sport fishing activities are also increasing in many areas of the giant otter's range including in the Pantanal, but reports of conflicts are not known. However, in Colombia, where commercial fishermen act as tourist fishing guides, conflicts have occurred (Gómez and Jorgenson, 1999).

Gold mining: Most Amazonian rivers or their tributaries have favorable conditions for mercury contamination (Uryu et al., 2001). Even in regions with low anthropogenic presence, mercury concentrations in rivers and lakes are naturally high and mercury bioaccumulation may occur due to the continuous metal release from soils, causing public health problems (Fadini and Jardim, 2001). As a consequence, any further input of mercury in the Amazonian rivers should be carefully evaluated.

Since the late 1970s the gold rush in the Amazon has caused serious environmental damage to its complex aquatic ecosystems. Studies have shown that poorly managed mining can create significant impacts through deforestation, cultural erosion and social conflict in rural communities that often capture only a nominal share of financial benefit but bear the weight of environmental and social costs (Hammond et al., 2007).

In areas of gold mining, mercury is concentrated as it passes from lower to higher trophic levels through the aquatic food web, a phenomenon known as bioaccumulation. Such unsafe concentrations of mercury present in the water, fish and sediments, pose serious threats to the giant otter, which depends on fish for its survival ${ }^{4}$ (Schenck and Staib, 1994; Boudou et al., 2005; Durrieu et al., 2005).

The mercury concentrations in the fish and people that have been sampled near gold mining areas in Guyana ${ }^{14}$ and in Suriname ${ }^{15}$ are higher than what is considered safe for humans. Similar unsafe levels have also been found in

\footnotetext{
${ }^{14}$ Singh, D., Watson, C. and Mangal, S. (1996) Identification of the sources and assessment of the levels of mercury contamination in the Mazaruni Basin in Guyana, in order to recommend mitigation measures. Institute of Applied Science and Technology report to the WWF-Guianas. Georgetown, Guyana. 10 pp.

${ }^{15}$ Qwik, J.A.M. and Ouboter, P. (2000) Water Quality Monitoring in the Commewijne Watershed, Suriname. World-Wildlife Fund and UNDP Guayana Forests \& Environmental Conservation Project (WWF-GFECP) 2000. Paramaribo, Suriname. 88 pp.
}

sampling studies in French Guiana (Richard et al., 2000). In Peru, the increase in gold-mining activity in the department of Madre de Dios has resulted in near local extinction of the species, with giant otters only surviving in tributaries and lakes where there is no mining activity (Groendendijk and Hajek, 2006). The level of mercury in fish muscle analyzed in that region showed evidence of mercury pollution, therefore a possible risk of mercury intoxication in the giant otter has been postulated (Gutleb et al., 1997). Furthermore, migration of contaminated fish and long-range atmospheric transport of mercury can enlarge the mining activities' area of influence. In a pristine area northeast of Peru, far from any gold-related activities, Gutleb et al. (2002) found that all metals were in the same range as those reported for non-polluted regions with the exception of total mercury, which was higher than the standard value established by legislation. Dias Fonseca et al. (2005) analyzed different organs and tissues of two giant otters found dead in the Pantanal, in a region where no gold mining activity is reported, and found no evidence of contamination. However, especially in Brazil, where hydroelectric dams are an important component of development plans, a synergic effect of gold mining and damming on mercury contamination in fish should be considered as observed by Boudou et al. (2005). They found that mercury mobilization related to gold mining account for even higher concentrations in fish when environmental conditions typical of a reservoir, such as anoxia, are present.

We can expect this problem will persist and expand in the Amazon for a long time. Consequences such as the contamination of aquatic ecosystems and its implications for wildlife and humans are likely to become more significant in the future due to the price-driven boom in gold mining. Over 25 years, for instance, the Guiana Shield region has seen exponential growth in gold extraction, with a 60-fold increasing in annual gold output (Hammond et al., 2007).

Hydroelectric dams: While hydroelectric dams may present major threats for giant otters (Pickles et al., 2012), there are still limited data to accurately evaluate the effects caused by these infrastructure elements on giant otter populations. As stated earlier, judging by the number of giant otter groups identified in only $10 \%$ of the Balbina hydroelectric lake (at least 35 groups present) it seems that in some instances such man-made lakes can sustain viable populations of giant otters (Rosas et al., 2007). Additionally, giant otters are semi-aquatic animals, known to be able to walk more than $4 \mathrm{~km}$ on land if necessary, including groups with young cubs ${ }^{16}$, it seems that the dam structures themselves may not act as genetic barriers as originally thought (Rosas et al., 1991). However, such dams attract the settlements of human populations on the lake margins and hitherto pristine areas became accessible after the lake is formed, creating eminent threats to the resident otters (Rosas et al., 2007). The higher anoxia levels

${ }^{16}$ M. Marmontel, pers. comm., 2008 
imposed by the lake tend to increase the presence of mercury in the food chain as well as modify the fish productivity and community. Furthermore, it is unknown how long artificial lakes will support large groups of giant otters and the effect on their reproductive success (Leuchtenberger et al., 2013).

Tourism: In recent years there has been a tremendous increase in the number of people visiting natural areas, a phenomenon known as ecotourism. The ecotourism industry has grown very rapidly to become an important economic force that depends on and therefore promotes the maintenance of healthy environments (Higham, 2007). Pristine areas with great biodiversity are the most sought after, making them valuable tools for conservation. Income from ecotourism can support protected areas and give local communities an economic incentive to maintain their surrounding environment hence benefiting many endangered species of plants and animals in the process (Pearce and Moran, 1994). However, tourists impact the environments they visit: the infrastructure of lodges and roads subdivide pristine habitats and increased human presence affects animal species sensitive to disturbance. Therefore ecotourism can be a powerful force for both the protection and the destruction of the habitats inhabited by giant otters.

Giant otters offer tourists not only the opportunity to spot a charismatic predator, but also a good chance to see a social species in the wild. As large, social, noisy and diurnal animals they are one of very few South American carnivores that are relatively easy to observe in the wild. Recognizing their aesthetic appeal, many wildlife tourism agencies promote them as a major tourist attraction all over their distribution range. Local communities practicing ecotourism also recognize their importance no longer regarding them as a competitor but as a valuable asset (Roopsind, 2002). Giant otters are usually very popular with tourists who want to approach them as closely as possible. As the increased customer satisfaction translates into higher economic returns, poorly managed tourism capitalizes on this appeal by charging tourists to see giant otters without taking into account their ecological needs. This is a risky approach and a balance must be established between beneficial and potentially harmful effects of the ecotourism in order to avoid further threats (Groenendijk and Hajek, 2006).

The most severe threat of tourism is related to the high sensitivity of reproductive female otters. In zoos, as a result of stress induced by the presence of visitors, the mother can stop lactating, failing to nurse her entire litter of cubs (Sykes-Gatz, 2005). Even though females are used to noisy zoo visitors, they become highly sensitive to outside influences when they have cubs. In the wild, Schenck and Staib (1994) observed that the reproductive success rate of three groups of giant otters living in three lakes heavily visited by tourists was onethird lower than anticipated.

In some regions, the peak of the tourism season is preceded by a few months by the peak in giant otter births and the otter mother must provide ample milk just when its home range shrinks and tourists arrive in droves (Schenck and Staib, 1994; Groenendjik and Hajek, 2006). As a general rule most otter families are much more wary when they are rearing young cubs and display a skittish behavior towards human visitors (Dauphine, 2001). However, in the narrow Pixaim River in Pantanal, where there is heavy tourist presence and feeding of the otters at the height of the cubbing season, the mother and cubs appeared unaffected (Duplaix, pers. obs.).

To place too much emphasis on a single species as a tourist attraction is risky, since it can result in disappointed visitors if their expectations are not met. Further, guides who feel pressured may go to considerable lengths to satisfy their customers and the otters can disappear altogether (Groenendjik and Hajek, 2006). Poorly managed tourism can also reduce habitat quality by clearing paths along shorelines, thereby preventing giant otters from digging their dens or establishing their campsites.

Despite the important implications both for economic development and for conservation, few studies to date have examined giant otters-tourist interactions in depth. Poorly managed tourism has been mentioned as an emerging problem in Brazil (Rosas et al., 2008b) and Peru (Schenck and Staib, 1994). In the Peruvian Amazon, where tourism is rapidly growing, the Frankfurt Zoological Society for the last 20 years has promoted the implementation of sound management solutions to reduce tourism impact. This includes increased education both for tourists and local guides, zoning and refuge areas for the otters, better trail design with protection of the shoreline, tight control of boats, and when possible the replacement of boat use with observation towers and platforms, as well as rules of minimum observation distance (Schenck and Staib, 1994; Groenendijk and Hajek, 2006). As a result tourism and giant otters do co-exist harmoniously in such protected areas ${ }^{17}$ (Dauphine, 2001). Both the authors monitored giant otter groups in the tourism-managed oxbow lakes Tres Chimbadas and found that, although the presence of boats on the lake affected otters, from eliciting alarm behavior to shortening fishing sessions, yet they swim, fish, relax, and use campsites on a regular basis when boats are present. Moreover the reproductive success does not seem affected and therefore they conclude that the management plan for the area is being successfully implemented to reduce human impacts.

Deforestation and climate change: The giant otter's distributional range includes and almost coincides with the Amazon Basin and Guiana Shield, which is not only the largest repository of global biodiversity but also a key component of the global carbon cycle, which is itself a determining factor for global climate (Malhi et al., 2008; Vergara and Scholz, 2011). It is well known that changes in land-cover can be a

\footnotetext{
${ }^{17}$ Dehnert, K. (2003) Human Impact on Giant Otters in Lake Tres Chimbadas. Tambopata Summer Research Opportunity, Tambopata, Peru. Stanford University, USA. 24 pp. [available from http://www.scribd.com/
} doc/88564858/Dehnert-Human-Impact-on-Tres-Chimbadas-2003] 
driver of climate change through a number of feedback loops (Cox et al., 2004; Malhi et al., 2008; Nepstad et al., 2008). On the other hand, current climate trends may unbalance the Amazon ecosystem and, in association with land use changes, may be shifting the region from a carbon sink to a carbon source (Vergara and Scholz, 2011). In principle, deforestation and global warming acting synergistically could lead to drastic biome changes hence representing a severe threat, potentially leading to a rapid decline of the giant otter populations caused by habitat degradation and habitat loss.

The Amazon region includes nine of the 13 countries where giant otters occur. In Brazil, the drivers of deforestation are manifold and have already reduced the forest cover for this region to about $80 \%$ of its original area (Davidson et al., 2012). Clearance is concentrated in the 'arc of deforestation' on the southern and eastern margins, driven primarily by expansion of cattle and by soybean production, which responds to international and national demands for livestock feed (Malhi et al., 2008; Davidson et al., 2012). Moreover, rising worldwide demands for biofuel is creating powerful new incentives for agro-industrial expansion (Nepstad et al., 2008). However, the overall direct footprint of human activity is much greater and widespread than deforestation alone and includes logging, hunting, pollution and fire across these nine countries (Colombia, Venezuela, Guyana, Suriname, French Guiana, Brazil, Ecuador, Peru, Bolivia). Road building is also one of the economic activities that stimulates deforestation by further encouraging a maze of new 'unofficial roads' that result as new colonists arrive (Nepstad et al., 2001; Davidson et al., 2012). It seems inevitable that the widespread conversion of forest into agricultural and pasture lands will continue unabated as part of the economic development of these Amazonian countries (Malhi et al., 2008).

Various global and regional climate-modeling approaches, combining climate change impacts, deforestation and fire effects, have predicted a large-scale substitution of Amazon forest by savannah-like vegetation, a phenomenon known as dieback (Cox et al., 2004; Malhi et al., 2008; Nepstad et al., 2008; Vergara and Scholz, 2011). These studies have shown that forest fires, drought and logging engender further burning while deforestation and smoke can inhibit rainfall, exacerbating fire risk. As deforestation and global warming proceed a 'tipping point' will be reached, whereby warmer temperatures and water stress will cause a large-scale dieback of the Amazon forest. Although there is no consensus on the prediction of the magnitude or spatial distribution of deforestation required to lead to a significant region-wide decrease in precipitation (Davidson et al., 2012), researchers agree that continued human destruction of the forest can push the climatic balance in the region in a direction that makes the dieback situation more likely (Vergara and Scholz, 2011). If sea surface temperature anomalies (such as El Niño episodes) and associated Amazon droughts of the last decade (2005 and 2010 were two 'once-in-a-century' catastrophic droughts just five years apart) continue, substantial impacts are expected by 2025-2030 and the situation will worsen by 2050 (Nepstad et al., 2008; Vergara and Scholz, 2011). Such conditions will severally impact the earth's biodiversity - and the giant otters in South America.

\section{Field Methodology, Monitoring and Age Estimation}

Aiming to standardize survey methods in giant otter studies, Groenendijk et al. (2005) present a comprehensive handbook in which they provide details on how to collect reliable, comparable and user-friendly data. Therefore, we are not going to repeat those proposed survey methods here, but instead just highlight some aspects regarding new field methodology and describe our own field experience with giant otters. It is highly recommended to keep in mind that simplicity and pragmatism are vital in order to be able to replicate the method throughout the species' range and that the associated cost and effort is optimized to justify carrying out surveys on as large a scale as possible.

Recording their throat mark pattern is important for some ecological studies. Indeed, curious giant otters usually approach boats every time humans enter their territories, but sometimes not long enough to allow the researcher to record all the throat patches of the otters in the group. If this is the case, we recommend using the vocalization playback technique (see Rosas, 2003), which more than $80 \%$ of the time brings back the whole group, thereby increasing the opportunity to record their individual markings. Nevertheless, despite not causing any harm to the animals, it is not recommended to first approach a giant otter group using the playback technique. This technique should only be used if the identification of the throat marks was not possible when the animals approached voluntarily.

Some giant otter groups become habituated to the presence of researchers in their territories while others, no matter how long the researchers survey the area, do not tolerate their proximity. In any case, it is recommended not to approach a group closer than $20-30 \mathrm{~m}$, and never to chase the groups.

Because giant otter communal latrines (Fig. 3A, B) are located by the water's edge and have a very conspicuous odor, finding them is an easy task. Fresh scats and mucus collected from communal latrines provide a source of non-invasive biological samples for genetic studies. According to Garcia et al. (2007) although the material derived from feces/mucus has very low amounts of DNA present and some contaminants, satisfactory results and high quality DNA sequences can be obtained from fresh giant otter feces and mucus. If the aim of the study is to investigate relatedness among individuals in a group, mucus collection is not useful. For this purpose, Ribas (2012) developed a methodology to sample free-ranging giant otters with biopsy darts which are projected using a dart attached to line and spinning reel allowing recovery of the dart. This semi-invasive technique caused little disturbance to the animals and was very successful in obtaining high quality tissue for molecular genetic analysis (Ribas, 2012). 
For seasonal movements, home range and habitat use studies throughout the year, radiotelemetry can be a powerful tool. This technique was used in giant otters in 2007 by Silveira et al. (2011) in the Araguaia River, Brazil but with unfortunate consequences: a nursing female otter succumbed probably due to stress during capture procedures. Therefore, the authors recommend not to catch nursing females or young cubs. Since then, giant otters have been successfully radiomarked and tracked in the Pantanal and Amazon biomes. The animals are caught with a funnel net fixed during the night at the entrance of the den. Details of the anesthetic dosage, the surgery to implant the radiotransmitters intraperitoneally and the postsurgical procedures can be found in Silveira et al. (2011).

A less invasive but promising technique is remote photography and video. The use of camera traps in monitoring giant otter populations was first suggested by Utreras and Pinos (2003) in Ecuador and a recent pilot study was carried out by Pickles et al. (2011c) in the Bolivian Amazon. Both studies show that otters react minimally to the trap's presence. Remote cameras and videos can be used to provide details on movement patterns in the activity area of each group, record the frequency of visits to campsites and daily activity patterns in dens and latrines (Leuchtenberger, 2012). Over time, pack membership, identity of the breeding pair, presence of offspring, sex determination and pregnancy can also be determined with these recording devices.

Age estimation: Age determination is essential to the development of estimates of life history parameters for assessment and management of endangered species. However, until recently age estimation in giant otters was based only on photo-identified free-ranging individuals, which precludes accuracy in determining the absolute age of the animals. According to Klevezal and Serezhenkov (1996) absolute age can provide valuable information to estimate an individual's growth rate and specific characteristics of reproduction and feeding. A reliable method to estimate age in giant otters, largely applied to several mammalian species, was tested by Oliveira $e t$ al. (2007) in canine teeth of giant otters and proved to be useful to determine the absolute age in this species. According to Oliveira et al. (2007), although no age estimates could be carried out in the dentine of the giant otter teeth due to a lack of conspicuousness of the growthlayer groups (GLGs) in this part of the teeth, the GLGs were readily observed in the cementum. The method was validated comparing the ages estimated by counting GLGs in the cementum to the known-age individuals indicating that GLGs in the cementum of giant otter teeth are deposited on an annual basis.

To our knowledge, the longevity record for captive giant otters was a male of 20 years that lived in captivity at the National Institute of Amazonian Research, Brazil (Oliveira et al., 2007), which is in agreement with the age of another giant otter male who died at 19 years and 8 months at the
Dortmund Zoo, Germany (Brandstätter, 2005). However, according to Oliveira et al. (2007) longevity of captive animals is not necessarily representative of the longevity of free-ranging individuals, as the longevity of free-ranging giant otters is estimated to be around 15 years (Davenport, 2010). Nevertheless, this estimation was based on a photo-identified otter and this method is sensitive to errors when estimating absolute age of animals.

\section{Status and Conservation}

According to Pickles et al. (2012) despite giant otter populations recovering in parts of their range, the species remains patchily distributed and it is unlikely that gene flow is currently occurring among the populations of northern South America (Amazonas, Orinoco and Guianas). Therefore, the authors recommend the re-establishment and maintenance of the complex pattern of connectivity within this metapopulation allowing the dispersal of the species via corridors among the Orinoco, Amazon and Guianas (Pickles et al., 2012).

Translocation of giant otters from areas where their populations now appear stable, such as the Pantanal, to areas where their numbers are still low are currently being considered. We urge caution in planning and implementing such activities. As we have discussed above giant otters require a minimum population mass to maintain long-term population viability. Reintroducing otters without an indepth assessment of the suitability of the habitat where they are to be released and releasing only a small number of otters may doom the project to failure.

Conservation recommendations: To identify giant otter conservation problems and to make recommendations on how best to address them, we must first understand the adaptations as semi-aquatic carnivores that giant otters make to live in complex tropical freshwater ecosystems. Unlike larger terrestrial carnivores, like the jaguar for instance, that have huge home ranges of 30000 ha or more to hunt in (Rabinowitz, 1986), giant otters exploit only a very small proportion of the habitat available. Otter home ranges are narrow bands of often less than 200ha along the riparian zone of a river, creek or lake and the swamps or oxbow lakes nearby - this may represent a tiny portion of a small river in a huge reserve like the Central Suriname Nature Reserve and in even larger parks like Manu in Peru ${ }^{4}$ (Duplaix, 1980; Groenendijk, 2006). Therefore, anthropogenic impacts in that small home range in the riparian corridors, and particularly those affecting the river and the fish stocks, will have a significant impact on the otters living there. Unlike the jaguar, giant otters cannot and will not retreat to a 'safe zone' deep within the rainforest.

In South America, and in other regions where roads are scarce, rivers are often the only means of access and transport for people. Communities build their villages on riverbanks and exploit both the forest and river resources. Giant otters and people have co-existed side by side for centuries and still 
do, as long as the villages remain small and otters are not hunted.

In the final analysis, our knowledge of giant otter biology, behavior and ecology has increased significantly over the last 40 years. Surveys, long-term studies, conservation programs and ecotourism facilities are in place in many countries. Giant otters have attracted attention and protection in all countries where they occur. However, the threats have increased, sometimes exponentially, as well. Forty years ago we worried about the effects of the commercial pelt trade, today gold mining activities, once few and far between, are rampant and the attendant mercury pollution and habitat destruction affect many of the once pristine and isolated watersheds. How can we insure that giant otter numbers will not plummet again, further isolating populations and threatening their survival? For us, the answer lies in harnessing the goodwill, understanding, and active participation of local stakeholders and, ultimately, networking with multiple partners at the local, regional, and even continental level. Local residents who share the rivers with the otters must become willing participants in otter conservation initiatives and this can only be accomplished through education, consensus-building, and economic incentives. Pollution, habitat degradation or destruction engenders food insecurity to riparian communities and conflicts are sure to follow. Livelihoods for both people and otters depend on healthy ecosystems; once gone or buried under mercury-laden silt, they are difficult to recreate.

Profound changes are coming quickly to hitherto pristine areas, especially in the Amazon region - dams, roads, settlers, cities - which will impact local stakeholders directly and may not bring the promised economic benefits but only further hardship to them and their environment (Nepstad et al., 2001). Building strong local networks will create the capacity for these communities to participate in the regional decisionmaking process before it reaches the conflict stage. Such a complex endeavor evolves over many years and requires financial support but it can be done. For instance, a small group of local inhabitants of the Jauaperi River, a tributary of the Negro River in the Brazilian Amazon, joined together in 1992 with the dual aims of improving the quality of their life and strengthening their capacity of managing their natural resources. The environmental integrity of this region is currently threatened at different levels (Evangelista and Tosi, this volume). Notwithstanding, through the founding of an NGO (Amazônia), the group managed to raise international funds to address the threats of habitat degradation, while offering sustainable economic alternatives. Their project worked as a magnet for the neighboring settlements, reversing the trend of emigration from rural areas to city slums, typical of the region. Within a few years the group expanded and the Xixuaú community was born. They built schools, small clinics, a computer centre, artesian wells and community gardens, installed solar energy and improved market access by river for local products. They created new economic opportunities for the inhabitants of the region, such as local crafts, selling of non-timber forest products, community-based ecotourism and support for scientific research, all managed by a local cooperative enterprise. The pristine rainforest that surrounds the Xixuaú is well guarded and all the former giant otters hunters are today esteemed guides for tourists and researchers.

However, while only the local people are in a position to offer this protection, the support of government agencies would ensure a permanent solution to the threats that many areas face. Therefore we recommend the expansion of protected areas throughout the entire area of distribution of this species. In order to avoid the isolation of giant otter populations, a matrix of large protected areas, including whole watersheds and connecting corridors should ensure limited fragmentation and good connectivity. Conservation programs should take into account the role of apex predators such as giant otters, which maintain the ecological equilibrium of the habitat. Conflicts with fishermen over partitioning of food resources could then be tackled through designating areas for the exclusive use by giant otters.

Moreover it is fundamental to manage the economic development of these areas in a way that maintains the inherent climatic resilience that the intact forest provides, and its vital contribution toward mitigating global warming. Key aspects include not only new protected areas but also new financial incentives, needed to act as a countervailing force to the economic pressures for deforestation.

\section{Acknowledgments}

N. Duplaix thanks the Jonathan and Kathleen Altman Foundation for its generous support of the IUCN-SSC Otter Specialist Group. E. Evangelista thanks the Columbus Zoological ParkAssociation and CoopXixuaú for their financial and logistic support to the Giant otter of Xixuaú project. F.C.W. Rosas thanks the Uatumã Biological Reserve (ReBio Uatumá/ICMBio), Associação dos Amigos do Peixe-boi da Amazônia (AMPA) by means of Projeto Mamíferos Aquáticos da Amazônia, financed by Programa Petrobras Socioambiental. Philadelphia Zoo/USA, Fundação O Boticário de Proteção à Natureza, Conselho Nacional de Desenvolvimento Científico e Tecnológico (CNPq), Fundação de Amparo à Pesquisa do Estado do Amazonas (FAPEAM) and Centro de Preservação e Pesquisa de Mamíferos e Quelônios Aquáticos (CPPMQA) of the Amazonas Energia/Eletrobras, for their financial and logistic support to Projeto Ariranha/INPA. 


\section{References}

Alves, L.C.P.D.S. and Andriolo, A. (2010) Preliminary characterization of the illegal trade in wild animals at the Liberdade street market in Manacapuru city, Amazonas State, Brazil. Sitientibus Série Ciências Biológicas 10(2): 236-243.

Anonymous (1972) Red Data Book: Mammalia, vol. 1. International Union of Conservation for Nature and Natural Resources. Morges, Switzerland.

Barnett, A., Shapley, B., Lehman, S., Henry, E. and Benjamin, P. (2000) Records of the giant otter, Pteronura brasiliensis, from Guyana. IUCN Otter Specialist Group Bulletin 17(1): 46-51.

Beccaceci, M.D. and Waller, T. (2000) Presence of the giant otter, Pteronura brasiliensis, in the Corrientes Province, Argentina. IUCN Otter Specialist Group Bulletin 17(1): 31-33.

Bezerra, B.M., Souto, A.S., Schiel, N. and Jones, G. (2011) Notes on vocalisations of giant otters in the flooded igapó forests of Jaú National Park, Amazonas, Brazil. Journal of Ethology 29(1): 169-175.

http://dx.doi.org/10.1007/s10164-010-0218-0

Bininda-Emonds, O.R.P., Gittleman, J.L., and Purvis, A. (1999) Building large trees by combining phylogenetic information: a complete phylogeny of the extant Carnivora (Mammalia). Biological Reviews (Cambridge) 74(2): 143-175. http://dx.doi.org/10.1017/S0006323199005307

Boudou, A., Maury-Brachet, R., Coquery, M., Durrieu, G. and Cossa, D. (2005) Synergic effect of gold mining and damming on mercury contamination in fish. Environmental Science \& Technology 39(8): 2448-2454.

http://dx.doi.org/10.1021/es049149r

Bozzetti, B.F.C., Cabral, M.M.M. and Rosas, F.C.W. (2015) Cub biometry, litter size and reproductive period of giant otters (Pteronura brasiliensis) at the Balbina Hydroelectric Reservoir, Amazonas, Brazil. Latin American Journal of Aquatic Mammals 10(2): 115-121. http://dx.doi.org/10.5597/lajam00203

Brandstätter, F. (2005) Observations on the age limit of the giant otter (Pteronura brasiliensis). Der Zoologischer Garten 75(3): 209-210.

Brandstätter, F. (2011) International Studbook for the Giant otter (Pteronura brasiliensis). Zoo Dortmund. Dortmund, Germany.

Buschiazzo, M., González, E.M. and Soutullo, A. (2015) What do we know about Pteronura brasiliensis in Uruguay? Latin American Journal of Aquatic Mammals 10(2): 156-158. http://dx.doi.org/10.5597/lajam00209

Cabral, M.M.M., Zuanon, J.A.S., De Mattos, G.E. and Rosas, F.C.W. (2010) Feeding habits of giant otters Pteronura brasiliensis (Carnivora: Mustelidae) in the Balbina hydroelectric reservoir, Central Brazilian Amazon. Zoologia 27(1): 47-53. http://dx.doi.org/10.1590/S1984-46702010000100008
Cabrera, A. and Yepes J. (1940) Mamiferos Sud-americanos (Vida, Costumbres y Descripcion). Compañia Argentina de Editores. Buenos Aires, Argentina.

Carrera-Ubidia, P.M. (2006) Giant Otters (Pteronura brasiliensis) and Humans in the Lower Yasuni Basin, Ecuador: Spacio-temporal Activity Patterns and Their Relevance for Conservation. M.Sc. Thesis in Wildlife Science. Oregon State University. Corvalis, OR, USA. 109 pp.

Carter, S.K. and Rosas, F.C.W. (1997) Biology and conservation of the giant otter Pteronura brasiliensis. Mammal Review 27(1): 1-26.

http://dx.doi.org/10.1111/j.1365-2907.1997.tb00370.x

Carter, S.K.R., Rosas, F.C.W., Cooper, A.B. and CordeiroDuarte, A.C.O. (1999) Consumption rate, food preferences and transit time of captive giant otter, Pteronura brasiliensis: Implications for the study of wild populations. Aquatic Mammals 25(2): 79-90.

Chehébar, C. (1991) News from Argentina. IUCN Otter Specialist Group Bulletin 6: 17-18.

Colares, E.P. and Best, R.C. (1991) Blood parameters of Amazon otters (Lutra longicaudis, Pteronura brasiliensis) (Carnivora, Mustelidae). Comparative Biochemistry and Physiology Part A: Physiology 99(4): 513-515.

http://dx.doi.org/10.1016/0300-9629(91)90124-U

Corredor Londoño, G. and Tigreros Muñoz, N. (2006) Reproduction, behaviour and biology of the giant river otter Pteronura brasiliensis at Cali Zoo. International Zoo Yearbook 40: 360-371.

Cox, P.M., Betts, R.A., Collins, M., Harris, P.P., Huntingford, C. and Jones, C.D. (2004) Amazonian forest dieback under climate-carbon cycle projections for the 21 st century. Theoretical and Applied Climatology 78: 137-156.

http://dx.doi.org/10.1007/s00704-004-0049-4

Dauphine, D.C. (2001) The Giant River Otter (Pteronura brasiliensis). Ecotourism, Biodiversity, and Wildlife Ecology in the Amazon Rainforest. Human Biology Honors Program. Stanford University, USA. 80 pp. [Available from http://www. scribd.com/doc/88564855/Dauphine-the-Tres-ChimbadasOtter-Project-2001]

Davenport, L.C. (2008) Behaviour and ecology of the giant otter (Pteronura brasiliensis) in oxbow lakes of the Manu Biosphere Reserve, Peru. Ph.D. Thesis. University of North Carolina at Chapel Hill, USA. 232 pp.

Davenport, L.C. (2010) Aid to a declining matriarch in the giant otter (Pteronura brasiliensis). PLoS ONE 5(6): e1138. doi:10.1371/journal.pone.0011385. 6 pp. 
Davidson, E.A., de Araújo, A.C., Artaxo, P., Balch, J.K., Brown, F., Bustamante, M.M.C., Coe, M.T., DeFries, R.S., Keller, M., Longo, M., Munger, J.W., Schroeder, W., SoaresFilho, B.S., Souza, C.M. and Wofsy, S.C. (2012) The Amazon basin in transition. Nature 481: 321-328.

http://dx.doi.org/10.1038/nature10717

Dias Fonseca, F.R., Malm, O. and Waldemarin, H.F. (2005) Mercury levels in tissues of giant otters (Pteronura brasiliensis) from the Rio Negro, Pantanal, Brazil. Environmental Research 98(3): 368-71.

http://dx.doi.org/10.1016/j.envres.2004.11.008

Duplaix, N. (1980) Observations on the ecology and behavior of the giant river otter Pteronura brasiliensis in Suriname. Revue Écologique (Terre et Vie) 34: 495-620.

Duplaix, N. (1982) Contribution à l'écologie et à l'éthologie de Pteronura brasiliensis (Carnivora, Lutrinae): Implications évolutives. Ph.D. Thesis. Université Paris-Sud. Orsay, France. $353 \mathrm{pp}$.

Durrieu, G., Maury-Brachet, R. and Boudou, A. (2005) Goldmining and mercury contamination of the piscivorous fish Hoplias aimara in French Guiana (Amazon basin). Ecotoxicology and Environmental Safety 60(3): 315-323. http://dx.doi.org/10.1016/j.ecoenv.2004.05.004

Evangelista, E. (2004) Change of partners in a giant otter alpha couple. IUCN Otter Specialist Group Bulletin 21(1): 1-5.

Evangelista, E.R. and Rosas, F.C.W. (2011) The home range and movements of giant otters (Pteronura brasiliensis) in the Xixuaú Reserve, Roraima, Brazil. IUCN Otter Specialist Group Bulletin 28A: 31-37.

Evangelista, E. and Tosi, C. (2015) First distribution survey of giant otter in the southeast of Roraima, Brazil, with notes on the OSG guidelines for a standardisation of Survey Method. Latin American Journal of Aquatic Mammals 10(2): 143-146. http://dx.doi.org/10.5597/lajam00206

Fadini, P.S. and Jardim, W.F. (2001) Is the Negro River Basin Amazon impacted by naturally occurring mercury? Science of the Total Environment 275(1-3): 71-82.

http://dx.doi.org/10.1016/S0048-9697(00)00855-X

Franco-de-Sá, J.F.O., Rosas, F.C.W. and Feldberg, E. (2007) Cytogenetic study of the giant otter Pteronura brasiliensis Zimmermann 1780 (Carnivora, Mustelidae, Lutrinae). Genetics and Molecular Biology 30(4): 1093-1096. http://dx.doi.org/10.1590/S1415-47572007000600011

Frank, K., Schenck, C. and Staib, E. (2002) The effect of habitat destruction, isolation and human induced stress on survival of the giant otter (Pteronura brasiliensis) in Peru. An assessment of management options using a Simulation model. IUCN/SSC Otter Specialist Group Bulletin 19A: 59-63.
Garcia, D.M., Marmontel, M., Rosas, F.W. and Santos, F.R. (2007) Conservation genetics of the giant otter (Pteronura brasiliensis (Zimmerman, 1780)) (Carnivora, Mustelidae). Brazilian Journal of Biology 67(4): 819-827. http://dx.doi.org/10.1590/S1519-69842007000500004

Geraci, J.R. and Lounsbury, V.L. (1993) Marine Mammals Ashore. A field guide for strandings. Texas A\&M University Sea Grant College Publication, Galveston, USA.

Gómez, J.R. and Jorgenson, J.P. (1999) An overview to the giant otter-fisherman problem in the Orinoco Basin of Colombia. IUCN Otter Specialist Group Bulletin 16(2): 90-96.

Gómez Serrano, J.R. (2003) Follow up to a rehabilitation of giant otter cubs in Colombia. IUCN Otter Specialist Group Bulletin 20(1): 42-44.

Gómez, J.R., Jorgenson, J.P. and Valbuena, R. (1999) Report on the rehabilitation and release of two giant river otter (Pteronura brasiliensis) pups in the Bita River (Vichada, Colombia). IUCN Otter Specialist Group Bulletin 16(2): 86-89.

Groenendijk, J. and Hajek, F. (2006) Giants of the Madre de Dios. Ayuda para Vida Silvestre Amenazada. Sociedad Zoologica de Francfort, Lima, Perú. 160 pp.

Groenendijk, J., Hajek, F., Duplaix, N., Reuther, C., Van Damme, P., Schenck, C., Staib, E., Wallace, R., Waldemarin, H., Notin, R., Marmontel, M., Rosas, F., De Mattos, G.E., Evangelista, E., Utreras, V., Lasso, G., Jacques, H., Matos, K., Roopsind, I. and Botello, J.C. (2005) Surveying and monitoring distribution and population trends of the giant otter (Pteronura brasiliensis). Guidelines for a standardisation of survey methods as recommended by the Giant Otter Section on the IUCN/SSC Otter Specialist Group. Habitat 16: 1-100. [Available from http://www.giantotterresearch. com/articles/04_12_16_Habitat_Nr_16_komplett.pdf]

Gutleb, A.C., Schenck, C. and Staib, E. (1997) Giant otter (Pteronura brasiliensis) at risk? Total mercury and methylmercury levels in fish and otter scats, Peru. Ambio 26(8): 511-514.

Gutleb, A.C., Helsberg, N. and Mitchell, C. (2002) Heavy metal concentration in fish from a pristine rainforest valley in Peru: a baseline study before the start of oil-drilling activities. Bulletin of Environmental Contamination and Toxicology 69: 523-529. http://dx.doi.org/10.1007/s00128-002-0093-7

Hagenbeck, C. and Wunnemann, K. (1991) Breeding the giant otter Pteronura brasiliensis at Carl Hagenbecks Tierpark. International Zoo Yearbook 31: 240-245.

Hammond, D.S., Gond, V., De Thoisy, B., Forget, P-M. and DeDijn, B.P.E. (2007) Causes and consequences of a tropical forest gold rush in the Guiana Shield, South America. Ambio 36(8): 661-670. http://dx.doi.org/10.1579/00447447(2007)36\%5B661:CACOAT\%5D2.0.CO;2 
Harris, C.J. (1968) Otters. A study of the recent Lutrinae. Weidenfled \& Nicolson, London, England.

Higham, J. (2007) Critical issues in Ecotourism: Understanding a complex tourism phenomenon. Elsevier Ltd., Amsterdam, Netherlands. 458 pp. [available from www.nubkk.nu.ac.th/ picnews/s_1264237581.0750668784.pdf]

Jacques, H., Pelsy, C. and De Thoisy, B. (2001) Giant otters in French Guiana: a preliminary report. IUCN Otter Specialist Group Bulletin 18A: 17-18.

Javier Diaz, H. and Sanchez, I.M. (2002) Historical and actual presence of the giant otter (Pteronura brasiliensis) on the lower Meta River, Department of Casanare - Colombian Orinoquia. IUCN Otter Specialist Group Bulletin 19(2): 97-102.

Kenagy, G.J. and Trombulak, S.C. (1986) Size and function of mammalian testes in relation to body size. Journal of Mammalogy 67(91): 1-22. http://dx.doi.org/10.2307/1380997

Klevezal, G.A. and Serezhenkov, V.A. (1996) Some perspectives of the use of large mammals in radio-ecological studies: Tooth enamel as a biological dosimeter. Zoologichesky Zhurnal 75(4): 55-592.

Koepfli,K-P.andWayne, R.K.(1998) Phylogeneticrelationships of otters (Carnivora: Mustelidae) based on mitochondrial cytochrome b sequences. Journal of Zoology 246: 401-416. http://dx.doi.org/10.1111/j.1469-7998.1998.tb00172.x

Koepfli, K-P., Deere, K.A., Slater, G.J., Begg, C., Begg, K., Grassman, L., Lucherini, M., Veron, G. and Wayne, R.K. (2008) Multigene phylogeny of the Mustelidae: Resolving relationships, tempo and biogeographic history of a mammalian adaptive radiation. BMC Biology 6. 22 pp.

Kruuk, H. (2006) Otters: ecology, behaviour and conservation. Oxford University Press, Oxford, UK.

Laidler, P.E. (1984) The behavioural ecology of giant otter in Guyana. Ph.D. Thesis. University of Cambridge, UK. 296 pp.

Lasmar, R.P., Lima, D.S. and Marmontel, M. (2013) What do local fishermen from the mid Solimôes river think about the giant river otter? Natural Resources, Aquidabã 3(1): 42-48.

Leuchtenberger, C. (2012) Ecologia espacial e comunicação vocal de ariranhas (Pteronura brasiliensis) no Pantanal. Ph.D. Thesis. Instituto Nacional de Pesquisas da Amazônia. Manaus, Brazil. 180 pp.

Leuchtenberger, C.M. and Mourão, G. (2008) Social organization and territoriality of giant otters (Carnivora, Mustelidae) in a seasonally flooded savanna in Brazil. Sociobiology 52(2): 257-270.

Leuchtenberger, C. and Mourão, G. (2009) Scent-marking of giant otter in the southern Pantanal, Brazil. Ethology 115(3): 210-216.

http://dx.doi.org/10.1111/j.1439-0310.2008.01607.x
Leuchtenberger, C., Oliveira-Santos, L.G.R., Magnusson, W. and Mourão, G. (2013) Space use by giant otter groups in the Brazilian Pantanal. Journal of Mammalogy 94(2): 320-330. http://dx.doi.org/10.1644/12-MAMM-A-210.1

Leuchtenberger, C., Sousa-Lima, R., Duplaix, N., Magnusson, W. and Mourão, G. (2014) Vocal repertoire of the social giant otter. Journal of the Accoustical Society of America 136(5): 2861-2875. http://dx.doi.org/10.1121/1.4896518

Lewis, A., Cuthbert, R., Denny, M., Gotto, K. and Hilton, G. (1997) The giant otter, Pteronura brasiliensis, in Cano la Brea, Sucre State, Venezuela. IUCN Otter Specialist Group Bulletin 14(2): 81-88.

Lima, D.S. and Marmontel, M. (2011) Return to the wild and reintegration of a giant otter (Pteronura brasiliensis) cub to its family group on Amaná Sustainable Development Reserve, Brazilian Amazon. Latin American Journal of Aquatic Mammals 9(2):164-167. http://dx.doi.org/10.5597/lajam00183

Lima, D.S., Marmontel, M. and Bernard, E. (2012) Site and refuge use by giant river otters (Pteronura brasiliensis) in the Western Brazilian Amazonia. Journal of Natural History 46(11-12): 729-739. http://dx.doi.org/10.1080/00222933.2011.654280

Machado, G.V.R., Rosas, F.C.W. and Lazzarini, S.M. (2002a) O arco aórtico e seus ramos, diretos e indiretos na ariranha (Pteronura brasiliensis Zimmermann, 1780 Carnivora: Mustelidae). Arquivos de Ciências Veterinárias e Zoologia da UNIPAR 5(2): 285.

Machado, G.V.R., Rosas, F.C.W. and Lazzarini, S.M. (2002b) Lobação pulmonar e divisóes bronquiais na ariranha (Pteronura brasiliensis Zimmermann, 1780). Arquivos de Ciências Veterinárias e Zoologia da UNIPAR 5(2): 289.

Machado, G.V.R., Rosas, F.C.W. and Lazzarini, S.M. (2002c) Sobre a formação da veia cava cranial na ariranha da Amazônia (Pteronura brasiliensis, Zimmermann, 1780). Arquivos de Ciências Veterinárias e Zoologia da UNIPAR 5(2): 293.

Machado, G.V.R., Rosas, F.C.W. and Lazzarini, S.M. (2009) Topografia do cone medular na ariranha (Pteronura brasiliensis, Zimmermann, 1780). Ciência Animal Brasileira 10(1): 301-305.

Machado, M.R.B. (2004) Bioacústica de ariranhas (Pteronura brasiliensis) (Carnivora: Mustelidae): discriminação vocal $e$ repertório. M.Sc. Thesis. Universidade Federal do Amazonas and Instituto Nacional de Pesquisas da Amazônia. Manaus, Amazonas, Brazil. 94 pp.

Malhi, Y., Roberts, J.T., Betts, R.A., Killeen, T.J., Li, W. and Nobre, C.A. (2008) Climate change, deforestation, and the fate of the Amazon. Science 319: 169.

http://dx.doi.org/10.1126/science.1146961 
McTurk, D. and Spelman, L. (2005) Hand-rearing and rehabilitation of orphaned wild giant otters, Pteronura brasiliensis, on the Rupununi River, Guyana, South America. Zoo Biology 24: 153-167. http://dx.doi.org/10.1002/zoo.20042

Mourão, G. and Carvalho, L. (2001) Cannibalism among giant otters (Pteronura brasiliensis). Mammalia 65(2): 225-227.

Munn, C.A.S. and Knörnschild, M. (2014a) The vocal repertoire of adult and neonate giant otters (Pteronura brasiliensis). PLoS ONE 9(11): e112562. http://dx.doi. org/10.1371/journal.pone.0112562

Munn, C.A.S., Urrutia, M.C. and Knörnschild, M. (2014b) Vocal individuality in cohesion calls of giant otters, Pteronura brasiliensis. Animal Behaviour 88: 243-252. http://dx.doi. org/10.1016/j.anbehav.2013.12.005

Nepstad, D., Carvalho, G., Barros, G., Alencar, A.C.A., Capobianco, J.P., Bishop, J., Moutinho, P., Lefebvre, P., Silva Jr, U.L. and Prins, E. (2001) Road paving, fire regime feedbacks, and the future of Amazon forests. Forest Ecology and Management 154(3): 395-407.

http://dx.doi.org/10.1016/S0378-1127(01)00511-4

Nepstad, C.D, Stickler, C.M., Soares-Filho, B. and Merry, F. (2008) Interactions among Amazon land use, forests and climate: prospects for a near-term forest tipping point. Philosophical Transactions of the Royal Society B: Biological Sciences 363: 1737-1746. http://dx.doi.org/10.1098/rstb.2007.0036

Oliveira, G.C.R., Rosas, F.C.W. and Barcellos, J.F.M. (2007) Age estimation in giant otters (Pteronura brasiliensis) (Carnivora: Mustelidae) using growth layer groups in canine teeth. Latin American Journal of Aquatic Mammals 6(2): 155160. http://dx.doi.org/10.5597/lajam00120

Oliveira, G.C.R., Barcellos, J.F.M., Lazzarini, S.M. and Rosas, F.C.W. (2011) Gross anatomy and histology of giant otter (Pteronura brasiliensis) and Neotropical otter (Lontra longicaudis) testes. Animal Biology 61: 175-183.

http://dx.doi.org/10.1163/157075511x566506

Parera, A.F. (1992) Present knowledge on the giant otter in Argentina. IUCN Otter Specialist Group Bulletin 7: 19-21.

Pearce, D. and Moran, D. (1994) The economic value of biodiversity. IUCN, Earthscan Publications Ltd., London, UK.

Pickles, R.S.A., McCann, N.P. and Holland, A.P. (2011a) Mammalian and avian diversity of the Rewa Head, Rupununi, Southern Guyana. Biota Neotropica 11(3): 237-251. http://dx.doi.org/10.1590/S1676-06032011000300021

Pickles, R.S.A., Groombridge, J.J., Zambrana Rojas, V.D., Van Damme, P., Gottelli, D., Kundu, S., Bodmer, R., Ariani, C.V., Iyengar, A. and Jordan, W.C. (2011b) Evolutionary history and identification of conservation units in the giant otter, Pteronura brasiliensis. Molecular Phylogenetics and Evolution 61(3): 616627. http://dx.doi.org/10.1016/j.ympev.2011.08.017
Pickles, R., Zambrana, V., Hoffmann-Heap, I., Salinas, A., Groombridge, J. and Van Damme, P. (2011c) An evaluation of the utility of camera traps in monitoring giant otter populations. IUCN Otter Specialist Group Bulletin 28(1): 39-45.

Pickles, R.S.A., Groombridge, J.J., Zambrana Rojas, V.D., Van Damme, P., Gottelli, D., Ariani, C.V. and Jordan, W.C. (2012) Genetic diversity and population structure in the endangered giant otter, Pteronura brasiliensis. Conservation Genetics 13(1): 235-245. http://dx.doi.org/10.1007/s10592-011-0279-9

Rabinowitz, A.R. (1986) Ecology and behaviour of the jaguar (Panthera onca) in Belize, Central America. Journal of Zoology 210: 149-159.

Recharte, M. and Bodmer, R. (2010) Recovery of the endangered giant otter Pteronura brasiliensis on the YavariMirin and Yavari Rivers: a success story for CITES. Oryx 44(1): 83-88. http://dx.doi.org/10.1017/S0030605309990196

Recharte, M., Bowler, M. and Bodmer, R. (2008) Potential conflict between fishermen and giant otter (Pteronura brasiliensis) populations by fishermen in response to declining stocks of arowana fish (Osteoglossum bicirrhosum) in northeastern Peru. IUCN Otter Specialist Group Bulletin 25(2): 89-93.

Reuther, C. (2004) Foreword. Page 3 in Groenendijk, J., Hajek, F.N., Duplaix, N., Reuther, C., Van Damme, P., Schenck, C., Staib, E., Wallace, R., Waldemarin, H., Notin, R., Marmontel, M., Rosas, F., De Mattos, G.E., Evangelista, E., Utreras, V., Lasso, G., Jacques, H., Matos, K., Roopsind, I. and Botello, J.C. (2005) Surveying and monitoring distribution and population trends of the giant otter (Pteronura brasiliensis). Habitat 16: 1-100.

Ribas, C. (2012) Grau de parentesco e relaçôes sociais em ariranhas (Pteronura brasiliensis). Ph.D. Thesis. Instituto Nacional de Pesquisas da Amazônia (INPA). Manaus, AM, Brazil. 83 pp.

Ribas, C. and Mourão, G. (2004) Intraspecific agonism between giant otter groups. IUCN Otter Specialist Group Bulletin 21(2): 89-93.

Ribas, C., Damasceno, G., Magnusson, W., and Leuchtenberger, C. (2012) Giant otters feeding on caiman: evidence for an expanded trophic niche of recovering populations. Studies in Neotropical Fauna and Environment 47(1): 19-23.

Richard, S., Arnoux, A., Cerdan, P., Reynouard, C. and Horeau, V. (2000) Mercury levels of soils, sediments and fish in French Guiana, South America. Earth and Environmental Science 124(3-4): 221-244.

Roopsind, I. (2002) Fish consumption by giant otters (Pteronura brasiliensis) in the North Rupununi Wetlands. B.Sc. Thesis. University of Guyana. Georgetown, Guyana. 76 pp. 
Rosas, F.C.W. (2003) Técnicas de campo que podem auxiliar no estudo de populaçóes naturais de ariranhas (Pteronura brasiliensis). Boletim da Sociedade Brasileira de Mastozoologia 38: 4 .

Rosas, F.C.W. (2004) Ariranha, Pteronura brasiliensis (Carnivora: Mustelidae). Pages 265-269 in Cintra, R. (Ed.) História Natural, Ecologia e Conservação de Algumas Espécies de Plantas e Animais da Amazônia. EDUA/INPA, Manaus, Brazil.

Rosas, F.C.W. and De Mattos, G.E. (2003) Notes on giant otter (Pteronura brasiliensis) behavior in the lake of the Balbina hydroelectric power station, Amazonas, Brazil. Latin American Journal of Aquatic Mammals 2(2): 127-129.

http://dx.doi.org/10.5597/lajam00042

Rosas, F.C.W., Colares, E.P., Colares, I.G. and Da Silva, V.M.F. (1991) Mamíferos aquáticos da Amazônia brasileira. Pages 405-411 in Val, A.L., Figliuolo, R. and Feldberg, E. (Eds) Bases Cientificas para Estratégias de Preservação e Desenvolvimento da Amazônia: Fatos e perspectivas, vol. 1. EDUA, Manaus, Amazonas, Brazil.

Rosas, F.C.W., Zuanon, J.A.S. and Carter, S.K. (1999) Feeding ecology of the giant otter, Pteronura brasiliensis. Biotropica 31(3): 502-506.

Rosas, F.C.W., Sousa-Lima, R.S. and Da Silva, V.M.F. (2003) Avaliação preliminar dos mamíferos do baixo Rio Purus. Pages 49-59 in de Deus, C.P., da Silveira, R. and Py-Daniel, L.H.R. (Eds) Piagaçu-Purus: Bases cientificas para a criação de uma reserva de desenvolvimento sustentável. IDSM, Manaus, Amazonas, Brazil.

Rosas, F.C.W., De Mattos, G.E. and Cabral, M.M.M. (2007) The use of hydroelectric lakes by giant otters (Pteronura brasiliensis): The case of Balbina dam in Central Amazonia, Brazil. Oryx 41(4): 520-624.

http://dx.doi.org/10.1017/S0030605307005121

Rosas, F.C.W., d'Affonseca Neto, J.A. and De Mattos, G.E. (2008a) Anesthesiology, hematology and serum chemistry of giant otters, Pteronura brasiliensis (Carnivora, Mustelidae). Arquivos de Ciências Veterinárias e Zoologia da UNIPAR 11(2): 81-85.

Rosas, F.C.W., Waldemarin, H. and De Mattos, G.E. (2008b) Ariranha, Pteronura brasiliensis (Zimmermann, 1780). Pages 800-801 in Machado, A.B.M., Drummond, G.M. and Paglia, A.P. (Eds) Livro Vermelho da Fauna Brasileira Ameaçada de Extinção. Fundação Biodiversitas, Belo Horizonte, Minas Gerais, Brazil.

Rosas, F.C.W., Rocha, C.S., De Mattos, G.E. and Lazzarini, S.M (2009a) Body weight-length relationships in giant otters (Pteronura brasiliensis) (Carnivora, Mustelidae). Brazilian Archives of Biology and Technology 52(3): 587-591. http://dx.doi.org/10.1590/S1516-89132009000300010
Rosas, F.C.W., Cabral, M.M.M., De Mattos, G.E. and Silva, R.E. (2009b) Parental and alloparental care of giant otters (Pteronura brasiliensis) in Balbina hydroelectric lake, Amazonas, Brazil. Sociobiology 54(3): 919-924.

Rosas-Ribeiro, P.F., Rosas, F.C.W. and Zuanon, J.A.S. (2012) Conflict between fishermen and giant otters Pteronura brasiliensis in Western Brazilian Amazon. Biotropica 44(3): 437444. http://dx.doi.org/10.1111/j.1744-7429.2011.00828.x

Santos, E. (1984) Entre o Gambá e o Macaco: Vida e Costumes dos Mamíferos do Brasil. Editora Itatiaia Ltda., Coleção Zoologica Brasílica, v.6, Belo Horizonte, Minas Gerais, Brazil. 287 pp.

Schenck, C. and Staib, E. (1994) Giant otter: a giant under even bigger pressure. Esta-Druck, S.Tafertshorfer Polling for the Frankfurt Zoological Society, Frankfurt, Germany. 203 pp.

Schenck, C. and Staib, E. (2002) Habitat requirements of giant otter (Pteronura brasiliensis) in Peru. IUCN/SSC Otter Specialist Group Bulletin 19A: 302-307.

Schenck, C., Groenendijk, J., Hajek, F., Staib, E. and Frank, K. (2002) Linking protected area conditions to species needs. Pages 341-357 in Bissonette, J.A. and Storch, I. (Eds) Landscape Ecology and Resource Management, Linking Theory with Practice. Island Press, Washington, DC, USA.

Schweizer, J. (1992) Ariranhas no Pantanal. Ecologia $e$ comportamento da Pteronura brasiliensis. EDIBRAN Editora Brasil Natureza Ltda., Curitiba, PR, Brazil.

Silveira, L., Furtado, M.M., Rosas, F.C.W., Silva, L.C., Cabral, M.M.M., Torres, N.M., Sollmann, R., Kouba, A. and Jácomo, A.T.A (2011) Tagging giant otters (Pteronura brasiliensis) (Carnivora, Mustelidae) for radio-telemetry studies. Aquatic Mammals 37(2): 208-212.

http://dx.doi.org/10.1578/AM.37.2.2011.208

Staib, E. (2005) Eco-etología del Lobo de Rio (Pteronura brasiliensis) en el sureste del Perú. Ayuda para vida silvestre amenazada. Sociedad Zoologica de Francfort Perú. Lima, Perú. 195 pp.

Staib, E. and Schenck, C. (1994). Giant otters and ecotourism in Peru. IUCN Otter Specialist Group Bulletin 9: 7-8.

Sykes-Gatz, S. (2005) Husbandry and management of the giant otter (Pteronura brasiliensis), 2.ed. Zoo Dortmund, Dortmund, Germany. 270 pp.

Tomás, W.M., Camilo, A.R., Ribas, C., Leuchtenberger, C., Borges, P.A.L., Mourão, G. and Pellegrin, L.A. (2015) Distribution and conservation status of giant otter (Pteronura brasiliensis) in the Pantanal wetland, Brazil. Latin American Journal of Aquatic Mammals 10(2): 107-114.

http://dx.doi.org/10.5597/lajam00202 
Uryu, Y., Malm, O., Thornton, I., Payne, I. and Cleary, D. (2001) Mercury contamination of fish and its implications for other wildlife of the Tapajós Basin, Brazilian Amazon. Conservation Biology 15(2): 438-446.

http://dx.doi.org/10.1046/j.1523-1739.2001.015002438.x

Utreras, V. and Araya, I. (2002) Distribution and conservation status of the Neotropical otter (Lutra longicaudis) and giant otter (Pteronura brasiliensis) in Ecuador. IUCN Otter Specialist Group Bulletin 19A: 365-369.

Utreras, V. and Pinos, L. (2003) Camera trap use for studying giant otters (Pteronura brasiliensis) in the Yasuní Biosphere Reserve, Ecuadorian Amazon. IUCN Otter Specialist Group Bulletin 20(2): 69- 71.

Utreras,V., Suarez, E.R., Zapata-Rios, G., Lasso, G. and Piños, L. (2005) Dry and rainy season estimations of giant otter, Pteronura brasiliensis, home range in the Yasuni National Park, Ecuador. Latin American Journal of Aquatic Mammals 4(2): 191-194. http://dx.doi.org/10.5597/lajam00085
Van Damme, P., Wallace, R., Swaenepoel, K., Painter, L., Ten, S., Taber, A., Gonzales Jimenes, R., Saravia, I., Fraser, A. and Vargas, J. (2002) Distribution and population status of the giant otter Pteronura brasiliensis in Bolivia. IUCN Otter Specialist Group Bulletin 19(2): 87-96.

Van Zyll de Jong, C.G. (1972). A systematic review of the Nearctic and Neotropical riverine otters (genus Lutra, Mustelidae, Carnivora). Royal Ontario Museum Life Sciences Contributions 80: 1-104.

Vergara,W. and Scholz, S.M. (2011) Assessment of the risk of Amazon dieback. World Bank Study, Washington DC, USA. 99 pp. http://dx.doi.org/10.1596/978-0-8213-8621-7

Zambrana, V. and Van Damme, P.R. (2011) Workshop: Regional Action Plan for the Giant Otter (Pteronura brasiliensis). Friends of Giant Otter Bulletin 18: 8-13. 


\section{APPENDIX I}

\section{STANDARD MEASUREMENTS OF OTTERS*}

Species:

Sex: $\square$ Male $\square$ Female Accession Number:

Location:

Field Number:

Date:

Collector:

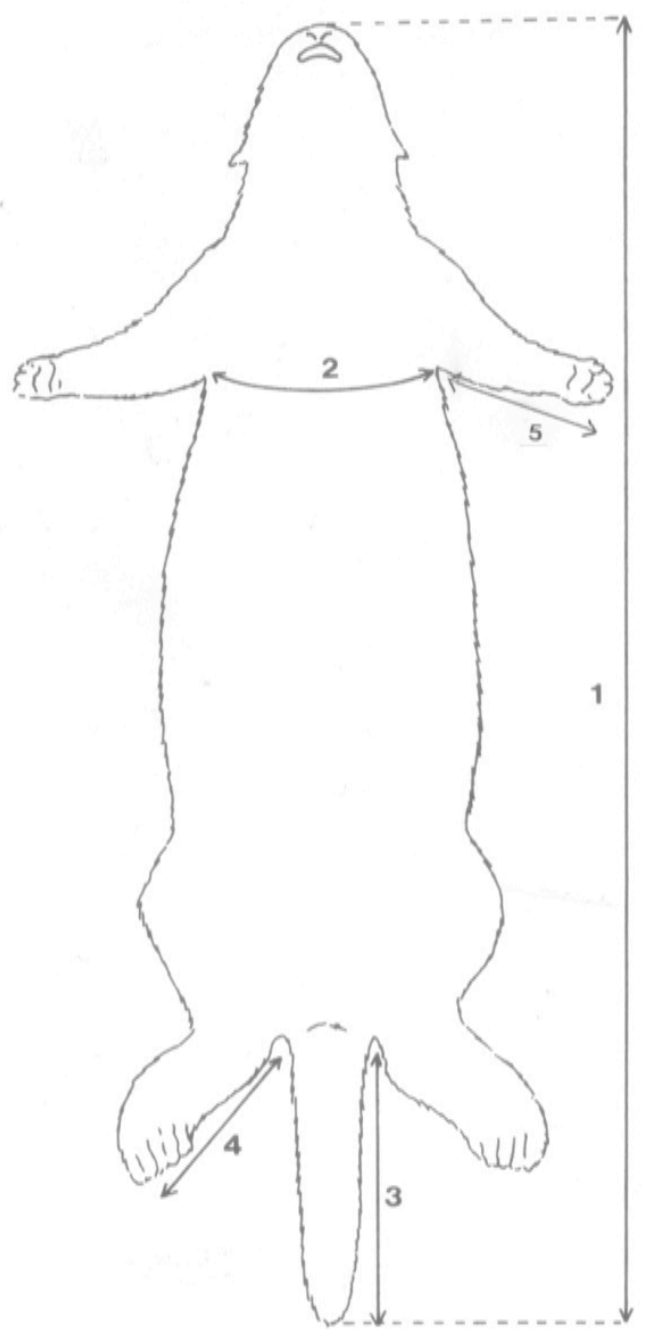

1) Total length $=$

2) Axillary girth $=$

3) Length of tail $=$

4) Length of foot $=$

5) Length of front paws $=$

Total weight $(\mathrm{kg})=$

*Modified from Geraci \& Lounsbury (1993) 